Columbia Law School

Scholarship Archive

2016

\title{
The WTO Dispute Settlement System 1995-2016: A Data Set and Its Descriptive Statistics
}

Louise Johannesson

Research Institute of Industrial Economics (IFN), louise.johannesson@ifn.se

Petros C. Mavroidis

Columbia Law School, petros.mavroidis@unine.ch

Follow this and additional works at: https://scholarship.law.columbia.edu/faculty_scholarship

Part of the Dispute Resolution and Arbitration Commons, and the International Trade Law Commons

\section{Recommended Citation}

Louise Johannesson \& Petros C. Mavroidis, The WTO Dispute Settlement System 1995-2016: A Data Set and Its Descriptive Statistics, EUROPEAN UNIVERSITY INSTITUTE, ROBERT SCHUMAN CENTRE FOR AdVANCEd Studies, Global Governance Programme Working Paper No. RSCAS 2016/72 (2016).

Available at: https://scholarship.law.columbia.edu/faculty_scholarship/2362

This Working Paper is brought to you for free and open access by the Faculty Publications at Scholarship Archive. It has been accepted for inclusion in Faculty Scholarship by an authorized administrator of Scholarship Archive. For more information, please contact scholarshiparchive@law.columbia.edu. 

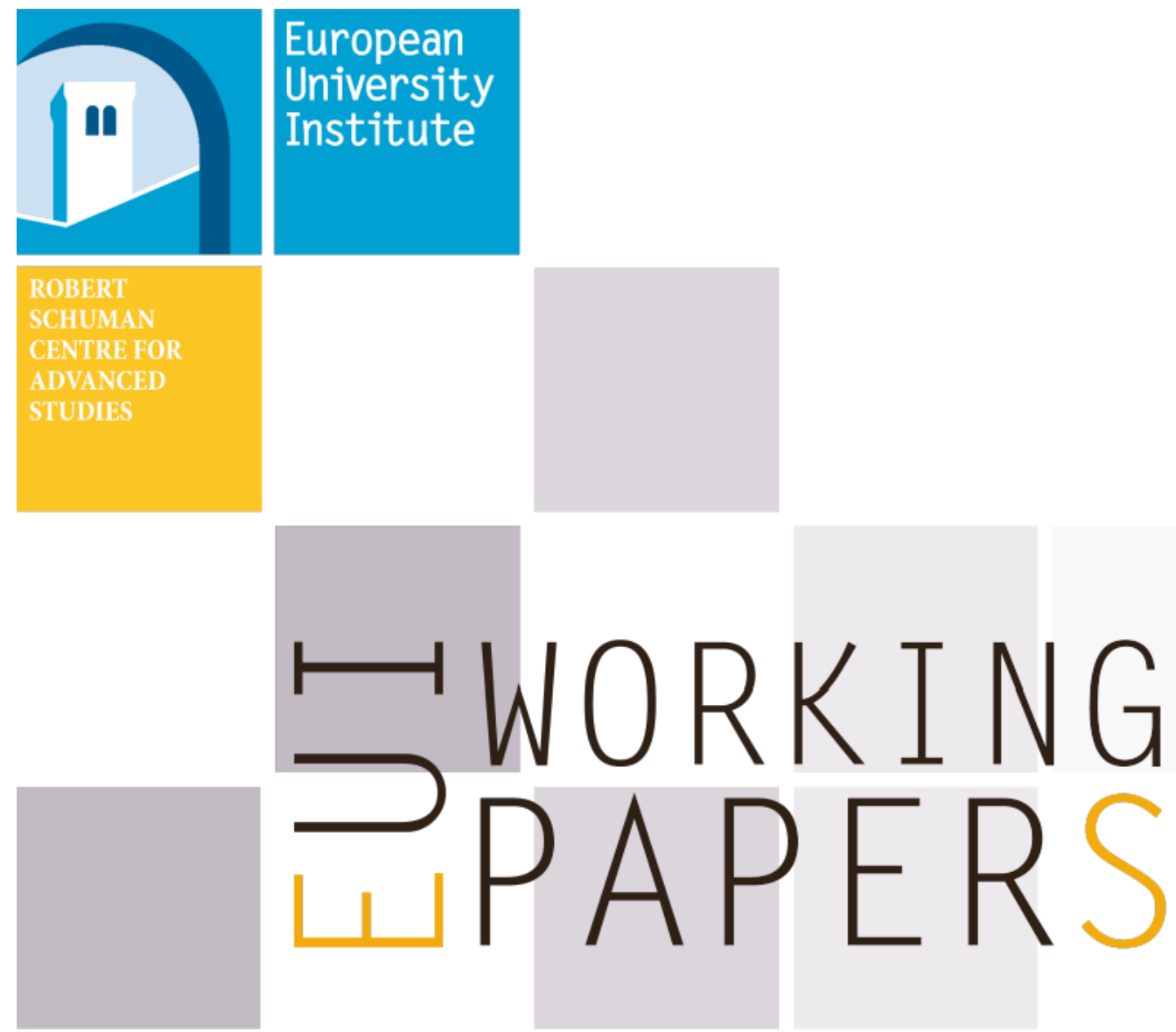

RSCAS 2016/72

Robert Schuman Centre for Advanced Studies Global Governance Programme-247

The WTO Dispute Settlement System 1995-2016: A Data Set and its Descriptive Statistics

Louise Johannesson and Petros C. Mavroidis 
European University Institute

Robert Schuman Centre for Advanced Studies

Global Governance Programme

The WTO Dispute Settlement System 1995-2016:

A Data Set and its Descriptive Statistics

Louise Johannesson and Petros C. Mavroidis

EUI Working Paper RSCAS 2016/72 
This text may be downloaded only for personal research purposes. Additional reproduction for other purposes, whether in hard copies or electronically, requires the consent of the author(s), editor(s). If cited or quoted, reference should be made to the full name of the author(s), editor(s), the title, the working paper, or other series, the year and the publisher.

ISSN 1028-3625

(C) Louise Johannesson and Petros C. Mavroidis, 2016

Printed in Italy, December 2016

European University Institute

Badia Fiesolana

I - 50014 San Domenico di Fiesole (FI)

Italy

www.eui.eu/RSCAS/Publications/

www.eui.eu

cadmus.eui.eu 


\section{Robert Schuman Centre for Advanced Studies}

The Robert Schuman Centre for Advanced Studies (RSCAS), created in 1992 and directed by Professor Brigid Laffan, aims to develop inter-disciplinary and comparative research on the major issues facing the process of European integration, European societies and Europe's place in $21^{\text {st }}$ century global politics.

The Centre is home to a large post-doctoral programme and hosts major research programmes, projects and data sets, in addition to a range of working groups and ad hoc initiatives. The research agenda is organised around a set of core themes and is continuously evolving, reflecting the changing agenda of European integration, the expanding membership of the European Union, developments in Europe's neighbourhood and the wider world.

Details of the research of the Centre can be found on: http://www.eui.eu/RSCAS/Research/

Research publications take the form of Working Papers, Policy Papers, and e-books. Most of these are also available on the RSCAS website:

http://www.eui.eu/RSCAS/Publications/

The EUI and the RSCAS are not responsible for the opinions expressed by the author(s).

\section{The Global Governance Programme at the EUI}

The Global Governance Programme is one of the flagship programmes of the Robert Schuman Centre for Advanced Studies at the European University Institute (EUI). It aims to: build a community of outstanding professors and scholars, produce high quality research and, engage with the world of practice through policy dialogue. At the Global Governance Programme, established and early career scholars research, write on and discuss, within and beyond academia, issues of global governance, focussing on four broad and interdisciplinary areas: European, Transnational and Global Governance; Global Economics; Europe in the World; and Cultural Pluralism.

The Programme also aims to contribute to the fostering of present and future generations of policy and decision makers through its unique executive training programme, the Academy of Global Governance, where theory and "real world" experience meet. At the Academy, executives, policy makers, diplomats, officials, private sector professionals and academics, have the opportunity to meet, share views and debate with leading academics, top-level officials, heads of international organisations and senior executives, on topical issues relating to governance.

For more information: http://globalgovernanceprogramme.eui.eu 



\begin{abstract}
In this paper, we provide some descriptive statistics of the first twenty years of the WTO (World Trade Organization) dispute settlement that we have extracted from the data set that we have put together, and made publicly available

(http://globalgovernanceprogramme.eui.eu/wto-case-law-project/). The statistical information that we present here is divided into three thematic units: the statutory and de facto duration of each stage of the process, paying particular attention to the eventual conclusion of litigation; the identity and participation in the process of the various institutional players, that is, not only complainants and defendants, but also third parties, as well as the WTO judges (panelists and Appellate Body members); and, finally, information regarding the subject-matter of various disputes, regarding the frequency with which claims regarding consistency of measures with the covered agreements (but also, at a more disaggregate level, e.g., specific provisions) have been raised. We call our work "descriptive statistics", because, in an effort to provide raw material that will help researchers to conduct their research as they see fit, we have consciously refrained from systematically interpreting the data that we have assembled.
\end{abstract}

\title{
Keywords
}

WTO; Dispute Settlement; Panel; Appellate Body

JEL Classification: K40 



\section{Introductory Remarks*}

The WTO dispute settlement system, often referred to as the crown jewel of the system, is unique in international relations in that it is the only comprehensive compulsory third party adjudication regime. Members of the WTO can solve disputes that might arise from the operation of the WTO contract, exclusively through recourse to the procedures established in the DSU, the Dispute Settlement Understanding, that is, the agreement organizing adjudication of disputes (Article 23.2 of DSU). WTO members, in other words, cannot take justice in their own hands, in application of the Roman Law maxim 'no one should be the judge of its own cause' (nemo judex in causa sua).

This (compulsory third party adjudication) is not the only remarkable feature of the DSU. To ease access to justice, or better, to avoid denial of justice, WTO members agreed during the Uruguay round to have their disputes adjudicated by independent, impartial judges every time that a willing complainant had expressed his desire to this effect. This is the notorious 'negative consensus', which complements Article 23.2 of DSU, in that it removes the possibility for defendants to block access to justice. ${ }^{1}$ These two provisions, along with the understanding that the WTO is a self-enforcing regime, ${ }^{2}$ make the 'DSU-think' so to speak, the quintessential features of WTO adjudication.

The DSU aims at removing disputes from the docket, if possible (Article 3.7 of DSU). If bilateral resolution fails, then the only way to resolve disputes, as already explained, would be through submission to an independent adjudicator. Losing parties will be called to comply with adverse rulings, or face retaliation equalling the damage inflicted through the illegal act.

More concretely, the WTO establishes a two-stage adjudication process, whereby disputes will be first submitted to panels ('first instance' courts, competent to discuss both the factual record, as well as the relevant legal discipline), and, eventually to the Appellate Body (AB), that is, the 'second instance' court within the WTO regime, the mandate of which does not allow it to extend its review beyond the understanding of the legal issues involved. Whereas the composition of panels depends every time on the preferences of WTO members and the WTO Secretariat, the AB has a 'fixed' composition, and its members serve for a four-year term, renewable only once.

Assuming a favourable for the complainant judgment, the defendant will be called to bring its measures into compliance with its obligations. If it fails to do so, it might be facing retaliation. If it manages to comply, the case will be resolved. For compliance to occur though, the agreement of the complainant, to the effect that the measures adopted were adequate, is necessary. In case of disagreement on this score, disputes will be submitted to 'compliance panels' (and eventually, the $\mathrm{AB}$ ), which are requested to pronounce on the adequacy of measures adopted during the reasonable period of time that defendants enjoy to this effect (Article 21.5 of DSU).

If defendant stays idle, or if a compliance panel (and/or the $\mathrm{AB}$, as the case may be) pronounce on the inadequacy of adopted measures, then defendant might be facing retaliation. The framers of the DSU did not manage to agree on a clear method to calculate the amount of retaliation. They used the term 'substantially equivalent concessions' that would serve as the legal benchmark for calculating

We would like to thank Aris Georgopoulos, and Bernard M. Hoekman for useful comments on prior drafts. The data set has been prepared thanks to financial assistance received from the European University Institute (EUI), Florence (Italy).

In his remarkable study, Hudec (1993) explains why acceding to compulsory third party adjudication and negative consensus was the product of incremental evolution, rather than paradigm shift. This is probably the reason why this example has not been emulated in other fora that have not witnessed similar institutional evolution in this respect. Mavroidis (2016) explains in detail the mechanics of the negotiation during the Uruguay round that established through statutory language the current regime.

2 By this, we mean that there is no possibility of third party enforcement in the WTO. It is WTO members that bring disputes against other WTO members, see Schwartz and Sykes (2002) on this score. 
retaliation. Disputing parties might disagree on the amount of retaliation, and disputes on this score will be submitted to an Arbitrator (the original panel, whenever possible), which will decide on the appropriate amounts (Article 22.6 of DSU). Awards by the Arbitrator on this score are not subject to appeal. $^{3}$ Retaliation can lawfully take place only following authorization to suspend (tariff) concessions (that is, raise the level of customs duties on imports from the recalcitrant WTO member). The defendant is still under the obligation to eventually bring its measures into compliance, and has to observe specific reporting requirements to this effect (Articles 21.6 and 22.8 of DSU). Suspension of concessions is 'temporary' as per the explicit wording of the DSU )Article 22.8 of DSU), but no statutory deadline for its expiry is provided. Consequently, whereas de jure the DSU (Article 22.1) calls for 'property rules', that is, for the obligation to perform the contract, de facto it tolerates 'liability rules', that is, the possibility for authors of an illegality to 'buy their way out of the contract'. ${ }^{4}$

This is, briefly, a description of the DSU, the subject-matter of our paper.

WTO courts, as a result of the institutional innovations mentioned above as well, continue, twenty years following their advent, to be the busiest courts litigating state-to-state disputes. In fact, at the moment of writing (December 31, 2016), 514 disputes had been initiated. ${ }^{5}$ Although the number of disputes has dwindled down over the years, WTO courts continue to be quite busy, as they adjudicate consistently over 15 disputes per year, as Table 1 shows.

Table 1: Average Number of Disputes per 5 year intervals

\begin{tabular}{c|c|c|c|c}
$1995-1999$ & $2000-2004$ & $2005-2009$ & $2010-2014$ & 2015 \\
\hline 39.4 & 28.9 & 16.3 & 19.5 & 13
\end{tabular}

3 The DSU is discussed in detail in Palmeter and Mavroidis (2006). Davey (2014) provides an excellent survey of its technical evolution over time, since the inception of the GATT.

4 Schwartz and Sykes (2000) detail how this can happen.

5 Our data set covers a slightly reduced number, and our unit of account (e.g., a "dispute") does not correspond with the unit of account used in the WTO webpage for the reasons that we explain later in Section 1 of this paper. 
Figure 1 (FORMER Figure 2.2) Average Number of Requests for Establishment of Panel per Year

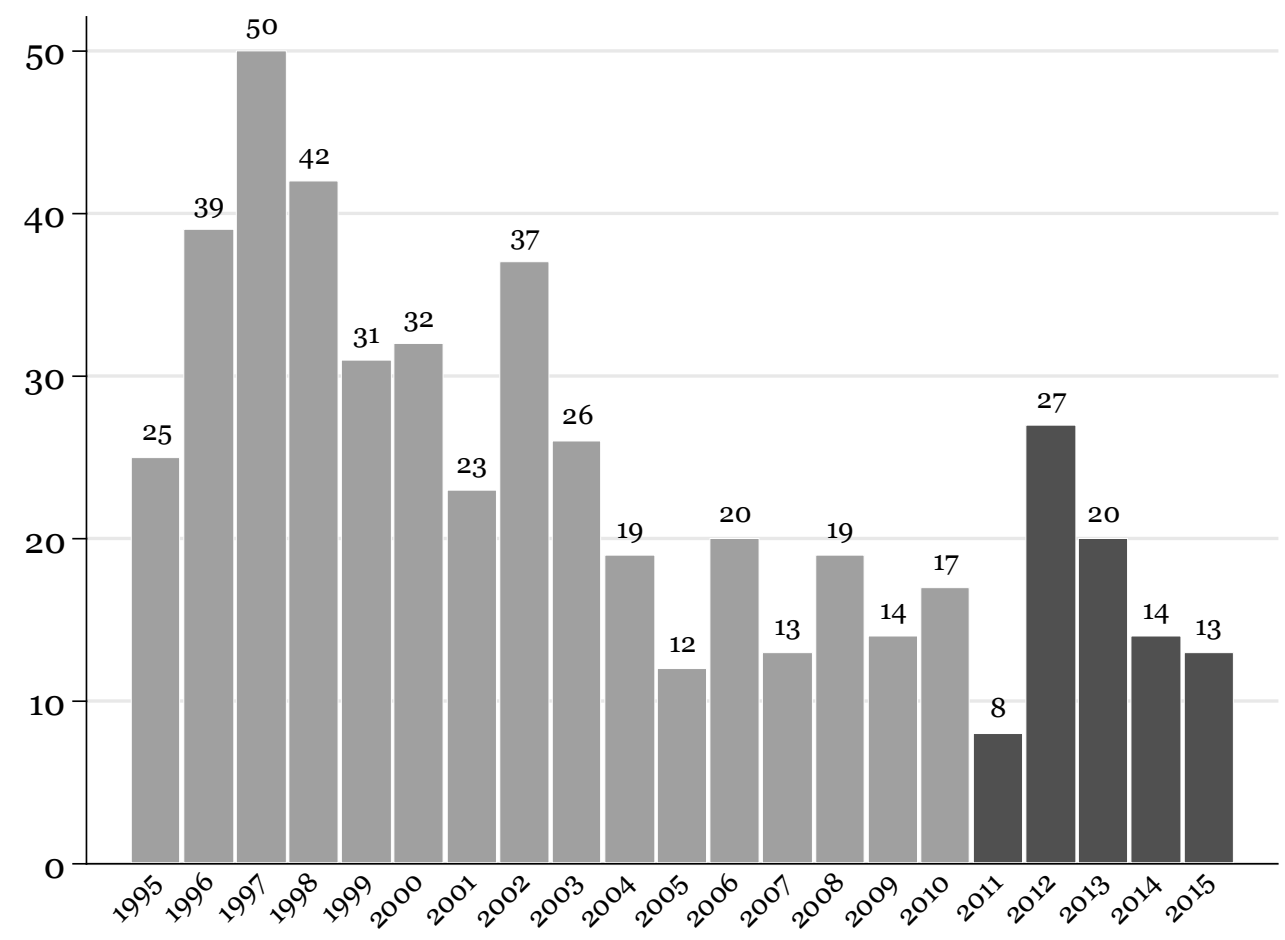

Figure 2 Average Number of Notices of Appeal per Year

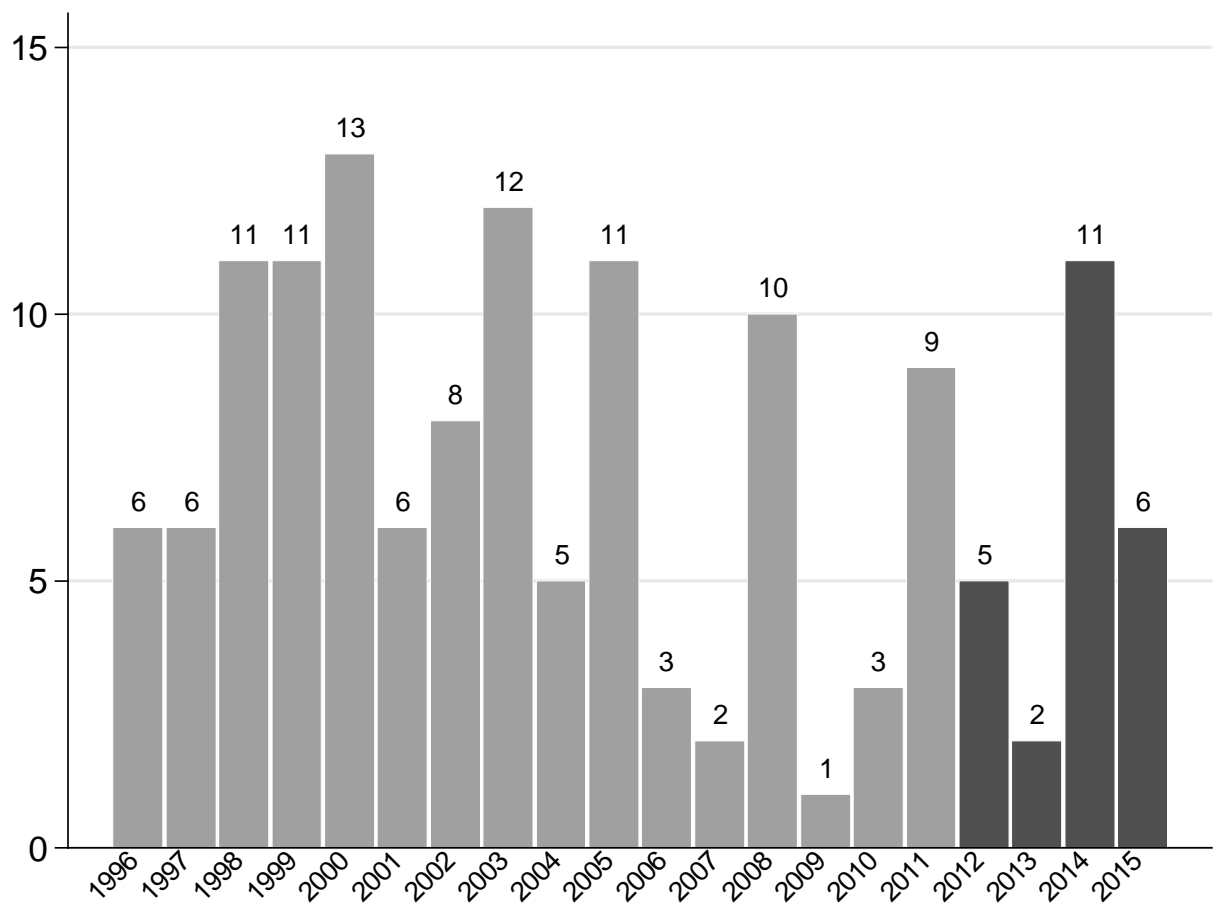


Figures 1, and 2, evidence the number of requests for consultations per year (Figure 1), as well as the number of disputes initiated before WTO panels, and the WTO Appellate Body (Figure 2). ${ }^{6}$ Absolute numbers do not, of course, tell a convincing story. And yet, when placed in context these numbers are quite impressive. Compare for example, with the number of disputes raised before the ICJ (International Court of Justice), which, like the WTO is a state-to-state court, but which, unlike the WTO adjudicates disputes in all areas of international law, and not simply trade. It has adjudicated so far, according to information provided in its official webpage, ${ }^{7}$ a total of 161 disputes. Were one to consider the fact that the number of states that can submit disputes to the ICJ surpasses that of the WTO membership by one third, that the ICJ has been hearing disputes since 1947 (as opposed to 1995 for the WTO), and that the ICJ also knows of nonlitigious procedures (advisory opinions, an impossibility as far as WTO courts are concerned), then one can better appreciate how busy WTO courts have been in the twenty years since their advent. Furthermore, as we will discuss in the concluding Section, even though the overall number of disputes has diminished in the last ten years (compared to the first ten), no forum diversion is observed. WTO members continue to submit their disputes before the WTO, and not to other bodies.

Compared to the 2011 edition of our data-set, ${ }^{8}$ we have included 81 more disputes in this edition. The total of disputes that we discuss here is 529 , but this number needs an explanation. We discuss all disputes raised between January 1, 1995, and June 30, 2016. According to the official WTO webpage (www.wto.org), DS 507 was the last dispute raised during that time. Some of the DS numbers between DS1 and DS507 nevertheless, could refer to multi-party disputes. We explain.

WTO disputes are, as we have briefly indicated already, formally initiated through filings of 'Requests for Consultations'. It could be the case that more than one complainant has drafted a 'Request for Consultations'. A single DS (dispute settlement) number (e.g., DS1, DS2 etc.) is assigned thus, to Requests of Consultations that might concern one complainant and one defendant, or more complainants and one defendant. We do not follow this method of counting. We convert the data into "bilateral" dispute form. That is, if two WTO members are complaining against a third member, we count each one of them as having one "dispute" each with the third member. A specific DS number could thus, be divided into two "bilateral" disputes. On the other hand, it is not always the case that two different dispute numbers are allocated when two distinct WTO members complain about the same measure, however.

To illustrate this point, we could refer to Argentina-Import Measures, where three complainants requested the establishment of a panel. Three different disputes were initiated and three different DS (dispute settlement) numbers were allocated to the litigation (DS438, 444, 445). We treat this litigation as three bilateral disputes. In EC-Bananas III, conversely, only one DS number (DS27) was allocated to a dispute involving five complainants against the EU (European Union). We treat this litigation as five bilateral disputes. ${ }^{9}$ We thus, arrive at the number 529 , the number of disputes that feature in our data set. ${ }^{10}$

6 As we explain in more detail in this Section, a WTO dispute is formally initiated through a request for consultations, which, if proved unsuccessful, could lead to a two-stage adjudication before panels (first instance), and the Appellate Body (second instance).

7 http://www.icj-cij.org/docket/index.php?p1=3\&p2=2

8 Horn et al. (2011).

9 This discrepancy is due to the fact that defendants can object to request by WTO Members to become co-complainants in disputes that have already been initiated, and/or disagreements regarding decisions to merge procedures relating to the same subject-matter (Articles 4.11 and 9 of DSU).

10 We are not advocating of course, that our counting method is more appropriate than, for example, that included in the DSU. It has the merit though of providing a symmetry with regard to the number of participants per disputes, as well as of being consistent with the method we have been using since we first established our data set. 
With all this information in the background, we can now move to discuss our data set. In Section 2, we provide information about the duration of the process, disaggregated in its different stages. We will be comparing statutory deadlines to practice. In Section 3, we focus on the institutional players. It is in this Section that we will be discussing the frequency of participation before panel and/or $\mathrm{AB}$ proceedings of the various complainants and defendants, as well as their percentage of wins and losses before panels and the $\mathrm{AB}$. In similar vein, we will be presenting our data regarding the identity of panellists and members of the $\mathrm{AB}$, the frequency of their participation in proceedings, and their national origin. Section 4 is dedicated to a discussion of the subject-matter of disputes. We will provide information at an aggregate- (the frequency of invoking specific agreements), as well at a disaggregated level (the frequency of invoking specific provisions). At the end of the day, the reader will have information regarding who (is complaining/complained against), what (is complained about), and how (disputes are resolved). In a short Section 5, we will present briefly the main conclusions of this study.

Before we go any further though, let us introduce at this stage our classification of the 164 now WTO members. The WTO does not formally distinguish between its members, other than a vague reference to developing countries. Nevertheless, WTO members are free to suggest whether they belong to one or the other category, and abuses have on occasion occurred. ${ }^{11}$ One subgroup of developing countries, namely the LDCs (least developed countries), that is, the poorest countries in the developing countries' group, is clearly determined in various WTO documents that have incorporated the UN (United Nations) classification to this effect. ${ }^{12}$ For the rest, the distinction between industrialized (developed), and developing countries is more like a line in the sand, than set in stone. We are thus, obliged to come up with our own classification. As with any other non-statutory classification, one might be accused for arbitrariness. In defence of our classification, we will state that we distinguish between homogeneous groups. There is lot of references in literature to the BRICS group, comprising of Brazil, China, Russia, India, and South Africa. It is true that they have on occasion formed a political alliance, as it is also true that they exhibit comparable levels of development. South Africa nevertheless, is one third of the population of Russia, the second least populated member of BRICS. As the size of the internal market is the main reason why we would like to distinguish BRICS from the other developing countries, we have instead cut out South Africa and distinguish between BRIC and remaining developing countries in our data set.

We thus distinguish between five groups, the first two belonging to the industrialized world, whereas the last three to the developing world:

G2 EU (European Union), and US (United States)

IND All members of the OECD (Organization of Economic Cooperation and Development), the club of industrialized countries, other than EU, US

BRIC Brazil, Russia, India, China, the biggest markets in the developing world

LDCs The least developed countries

DEV All remaining developing countries

11 For a discussion of this issue, see Mavroidis (2016a), vol. 1, Chapter 5.

12 The latest UN resolution adopting the list of LDCs is UN Doc. A/RES/70/253, of February 12, 2016. It comprises 48 countries. Since graduation to the developing countries group is possible (as is retrocession to the LDCs group), the list announces that five years from its adoption, Angola will graduate (as of February 2, 20121). 
The emerging picture thus, is as follows:

\section{Table 2: Our Classification of the WTO Membership}

\begin{tabular}{|c|c|c|c|}
\hline G2 & Brunei Darussalam & Namibia & LDC \\
\hline EU & Cabo Verde & Nicaragua & Angola \\
\hline \multirow[t]{2}{*}{ US } & Cameroon & Nigeria & Bangladesh \\
\hline & Chile & Oman & Benin \\
\hline BRIC & Colombia & Pakistan & Burkina Faso \\
\hline Brazil & Congo & Panama & Burundi \\
\hline India & Costa Rica & Papua New Guinea & Cambodia \\
\hline Russian Federation & Côte d'Ivoire & Paraguay & Central African Republic \\
\hline \multirow[t]{2}{*}{ China } & Cuba & Peru & Chad \\
\hline & Dominica & Philippines & Congo, Dem. Rep. of \\
\hline IND & Dominican Republic & Qatar & Djibouti \\
\hline Australia & Ecuador & Saint Kitts and Nevis & Gambia \\
\hline Canada & Egypt & Saint Lucia & Guinea \\
\hline Croatia & El Salvador & $\begin{array}{l}\text { Saint Vincent \& the } \\
\text { Grenadines }\end{array}$ & Guinea-Bissau \\
\hline Hong Kong, China & Fiji & Samoa & Haiti \\
\hline Israel & Gabon & Saudi Arabia & Lao \\
\hline Japan & Georgia & Seychelles & Lesotho \\
\hline Korea & Ghana & South Africa & Madagascar \\
\hline Liechtenstein & Grenada & Sri Lanka & Malawi \\
\hline Mexico & Guatemala & Suriname & Maldives \\
\hline New Zealand & Guyana & Swaziland & Mali \\
\hline Norway & Honduras & Chinese Taipei & Mauritania \\
\hline Singapore & Indonesia & Tajikistan & Mozambique \\
\hline Switzerland & Jamaica & Tanzania & Myanmar \\
\hline \multirow[t]{2}{*}{ Turkey } & Jordan & Thailand & Nepal \\
\hline & Kazakhstan & Macedonia & Niger \\
\hline DEV & Kenya & Tonga & Rwanda \\
\hline Albania & Kuwait & Trinidad and Tobago & Senegal \\
\hline Antigua and Barbuda & Kyrgyz Republic & Tunisia & Sierra Leone \\
\hline Argentina & Macao, China & Ukraine & Solomon Islands \\
\hline Armenia & Malaysia & United Arab Emirates & Togo \\
\hline Bahrain & Mauritius & Uruguay & Uganda \\
\hline Barbados & Moldova & Venezuela & Vanuatu \\
\hline Belize & Mongolia & Viet Nam & Yemen \\
\hline Bolivia & Montenegro & Zimbabwe & Zambia \\
\hline Botswana & Morocco & & \\
\hline
\end{tabular}

\section{The Process}

In this Section, we discuss the various statutory deadlines applicable to the various stages of the process, and compare them with practice. 


\subsection{The Importance of Statutory Deadlines}

Contrary to GATT practice, the DSU provides for specific deadlines within which each stage of the process must be completed. Various provisions of the DSU stipulate thus, time limits that, in principle, should be observed. As an illustration, we mention the following:

a) Article 4.7 of DSU states that the complainant can, sixty days after the receipt of the Request for Consultations, assuming that no satisfactory solution has been found by that time, request the establishment of a panel;

b) Parties to the dispute can request from the WTO DG (Director-General) to appoint panelists, if they have not managed to agree upon the panel composition within twenty days (Article 8.7 of DSU);

c) Proceedings before panels should not exceed six months, unless panels, after it has informed the DSB (Dispute Settlement Body), ${ }^{13}$ feel that they require nine months to complete their review of the case (Article 12.9 of DSU);

d) In similar vein, proceedings before the $A B$ should not exceed sixty days, unless the $A B$, having informed the DSB, decides that it needs ninety days to complete its review of the case before it (Article 17.5 of DSU).

Appendix 3 to the DSU provides in its paragraph 12 an indicative list of the time-table for the whole process. Why did the members of the WTO decide to restrain time-wise each stage of the process? To a large extent this was a US request during the negotiations.

The last years of the GATT are marked with an unusually high percentage of unadopted panel reports, as Hudec (1993) explains in his study. ${ }^{14}$ The US was at the receiving end of this practice, which to a large extent concerned disputes about farm trade. Since it could not obtain justice before the GATT, the US took, in a matter of speaking, justice to its own hands, aggressively enforcing its own perceptions of international trade on its trading partners. Section 301, a rather innocuous instrument, which was part and parcel of the US Trade Act of 1974 and which was designed to serve as instrument for private parties to alert the USTR (United States Trade representative), and persuade it to represent their claims in fora where only governments had standing, became anathema to the world trading community. Section 301 offered to private parties to alert the USTR about 'illegal' (in the US view) trade practices by foreign nations in areas not covered by the GATT, like services and intellectual property, which US lobbies cherished, and wanted to see international trading rules emerge. ${ }^{15}$

13 The DSB is the body administering the DSU. It decides all issues by consensus, as per the usual GATT/WTO practice, except for decision regarding the request for consultations, establishment of panel/AB, adoption of panel/AB report, arbitration to determine the reasonable period of time and/or the level of countermeasures, where it adopts its decisions on negative consensus. Each member of the WTO has one representative at the DSB.

14 All reports by GATT panels were submitted to the CONTRACTING PARTIES (the term expressed in block letters refers to the highest GATT organ). Unless adopted by consensus, panel reports would have no legal value, and would become relevant only if subsequent panels dealing with the same issue were persuaded by the reasoning therein. At any rate, unadopted panel reports would not oblige the unsuccessful defendant to implement their rulings. The GATT refers of course, to the General Agreement of Tariffs and Trade, the predecessor to the WTO. Following the advent of the WTO, the GATT was reduced from a de facto international organization, to an agreement regulating trade in goods coming under the aegis of the WTO, the institutional umbrella for trade liberalization.

15

Bhagwati (1990), and Milner (1990) explain how, in defiance of the coverage of the GATT, US lobbies managed to advance their agenda, and how, based on similar requests, the US government requested during the Uruguay round the extension of the international trading regime to cover trade in services (what eventually became the GATS, General Agreement on Trade in Services), and intellectual property rights (what became the TRIPs, Trade Related Intellectual Property Rights) in the WTO-era. 
Crucially, action under Section 301 was subjected to specific deadlines that the USTR had to comply with when processing private requests for relief. ${ }^{16}$ Mavroidis (2016) studied the negotiating record, and reports that a very substantial part of the DSU negotiation focused on emulating the Section 301 deadlines at the multilateral level. The idea was that, by adopting a strict calendar for processing disputes at the multilateral level, as well as by doing away with the onerous consensusrequirement for establishment of panels and adoption of their reports, the US would be, as a quid pro $q u o$, willing to abandon aggressive unilateralism, and accept submission of all trade disputes to compulsory third party adjudication. In this respect, the bargain has proved a success.

Statutory deadlines thus, are not a trivial issue as it might seem, but a rather important negotiated settlement.

\subsection{Practice}

With this is in mind we provide, in what now follows, a series of tables that detail the duration of each stage of the proceedings in practice. We start with a generic Table, which relays the duration for each stage of the proceedings.

Table 3: Duration of Each Stage of Proceedings

\begin{tabular}{|c|c|c|c|}
\hline \multicolumn{2}{|c|}{ Average length of process, months } & \multirow{2}{*}{$\begin{array}{c}\text { Statutory } \\
\text { deadline }\end{array}$} & \multirow{2}{*}{$\begin{array}{l}\text { Mean } \\
6.6\end{array}$} \\
\hline Consultations & $\begin{array}{l}\text { From the date of Request of consultations to the } \\
\text { establishment of panel }\end{array}$ & & \\
\hline $\begin{array}{l}\text { Panel } \\
\text { proceedings }\end{array}$ & $\begin{array}{l}\text { From the establishment of panel to circulation of the } \\
\text { panel report }\end{array}$ & 6 months & 15.1 \\
\hline Appeals & $\begin{array}{l}\text { From the date of the Notice of Appeal until the date } \\
\text { of the circulation of the Appellate Body }\end{array}$ & $\begin{array}{l}2-3 \\
\text { months }\end{array}$ & 3.3 \\
\hline $\begin{array}{l}\text { RPT, Bilateral } \\
\text { agreement }\end{array}$ & $\begin{array}{l}\text { Total length of agreed period between parties of RPT } \\
\text { during which implementation must occur. }\end{array}$ & & 11.6 \\
\hline $\begin{array}{l}\text { RPT, Arbitration } \\
\text { Award }\end{array}$ & $\begin{array}{l}\text { The average RPT awarded by the arbitrator in the } \\
\text { awards circulated. }\end{array}$ & & 9.6 \\
\hline $\begin{array}{l}\text { Compliance } \\
\text { panel }\end{array}$ & $\begin{array}{l}\text { From the date of the request to establish a first } \\
\text { compliance panel until the date of circulation of the } \\
\text { Compliance Panel Report. }\end{array}$ & 3 months & 8.7 \\
\hline AB compliance & $\begin{array}{l}\text { From the date of the first Notice of Appeal until the } \\
\text { date of circulation of the Appellate Body compliance } \\
\text { report. }\end{array}$ & & 3.4 \\
\hline
\end{tabular}

16 Hippler Bello and Holmer (1990), and Hudec (1990) explain the statutory language and rationale for this issue in detail. 
The reader would realize by comparing practice to statutory deadlines that the former almost always exceeds the latter, a point to which we will return at the end of this Section. Furthermore, there is evidence by now that it pays to make unreasonable demands when there is discretion to decide on the duration of a process. Under Article 21.3(c) of DSU for example, it is an Arbitrator that will decide on the reasonable period of time during which implementation of rulings included in a panel and/or $\mathrm{AB}$ report should occur. The DSU provides for a statutory limit (fifteen months), which serves as guideline, Arbitrators remaining free to decide on longer (as well as on shorter) periods for implementation. Empirical research by Mavroidis et al. (2017) shows that complainants consistently request for short, even on occasion unrealistic periods of implementation, whereas defendants for lengthy periods. Arbitrators almost smack dab to the middle the period within which they decide that implementation should occur.

Similar evidence is available from practice under Article 22.6 of DSU. ${ }^{17}$ Complainants will overshoot the damage they have suffered as a result of illegalities, whereas defendants will underestimate it. Arbitrators will almost always come up with numbers between the two.

With this in mind, we now turn to more disaggregated data regarding specific stages of the process, and we kick off our discussion with data regarding the duration of consultations.

Figure 3: Duration of Consultations

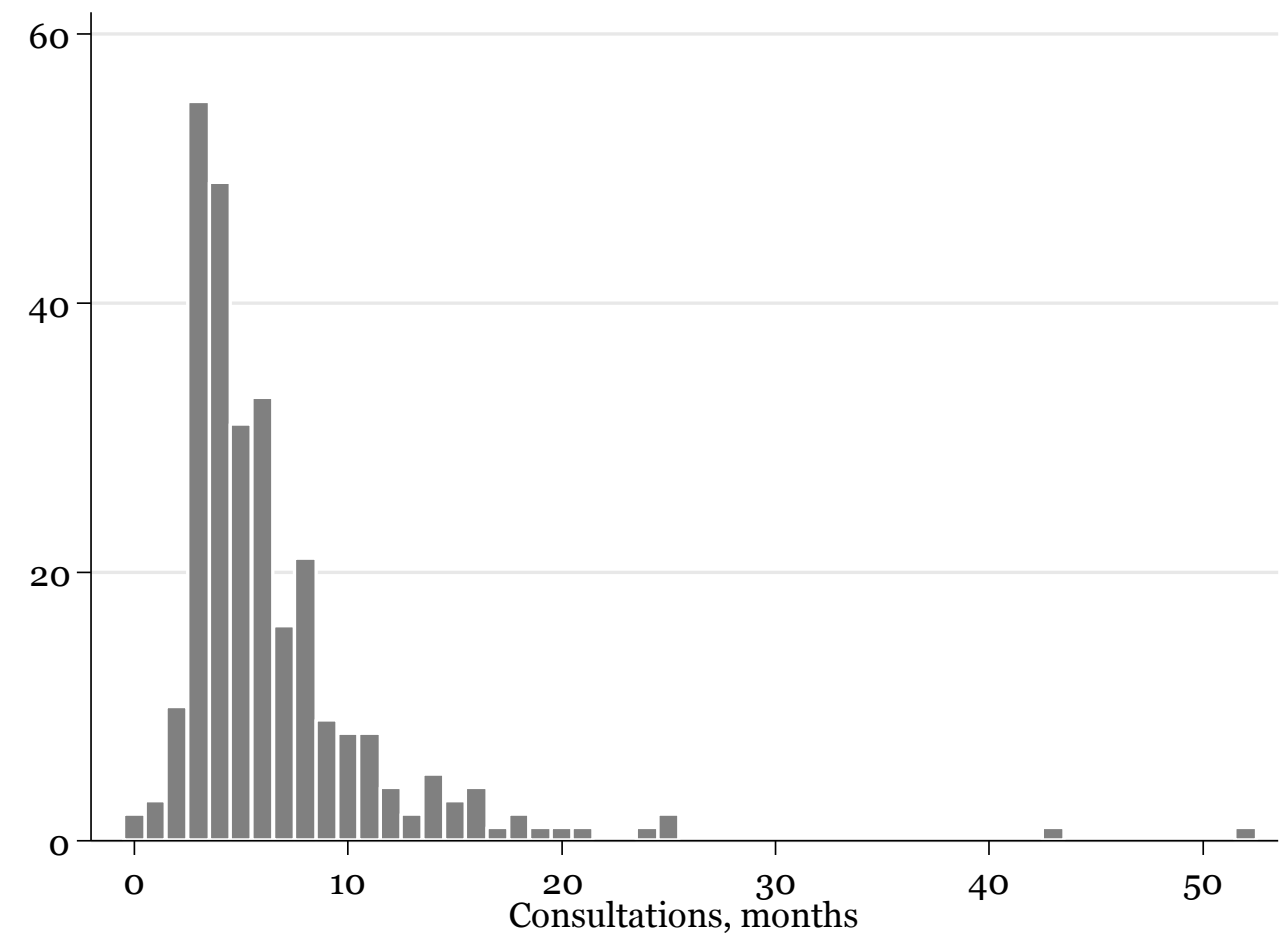

17 Bown and Brewster (2016) discuss this issue in detail. 
Table 4: Duration of Consultations by Group

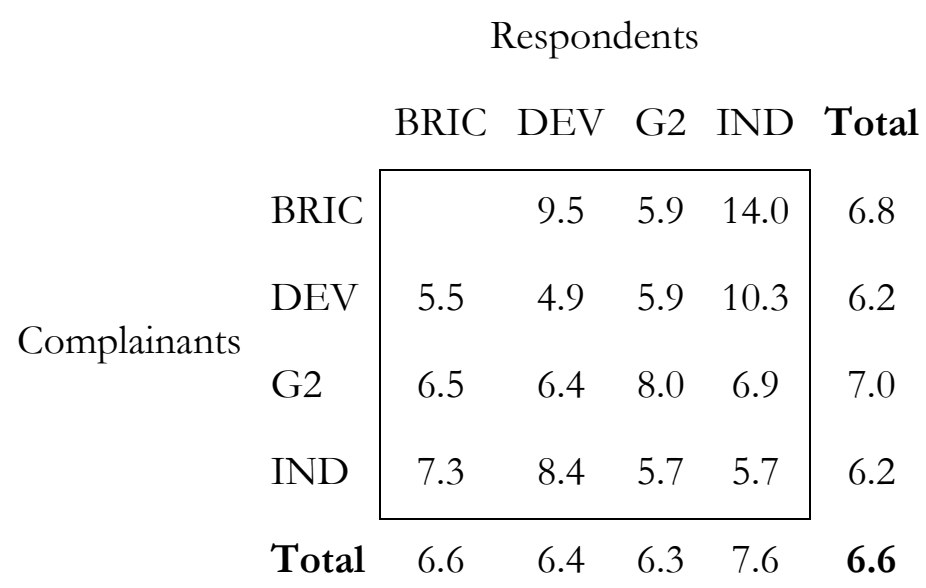

It follows that, whereas complainants can request establishment of a panel sixty days after the receipt of the Request for Consultations (Article 4.7 of DSU), in practice the average consultation lasts substantially longer. Busch and Reinhardt (2001) have discussed this issue, and show why it might be in the interest of both parties (on occasion) to press for a deal through consultations, than to bring their dispute out in the open. ${ }^{18}$ Although, as we show in the Table that follows, the propensity to resolve a dispute through consultations has been reduced over time, still almost two thirds of all disputes formally raised before the WTO are resolved at this stage of the proceedings.

18 Compare Guzman and Simmons (2003). 
Figure 4: Settlements at Consultations in Time-Series Mode

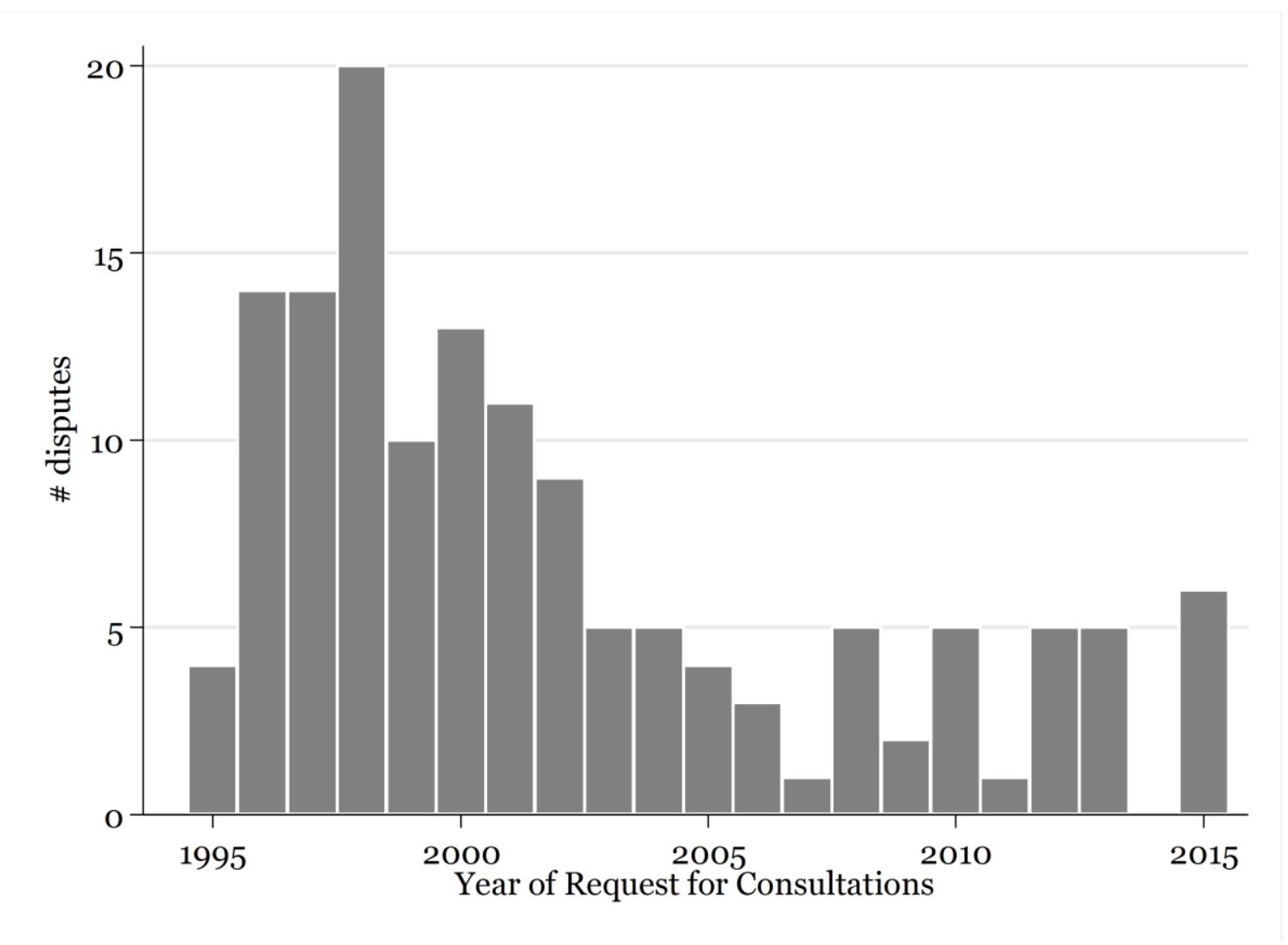

We now shift to discuss duration of panel and $\mathrm{AB}$ proceedings in practice. We provide information regarding the mean (how long do panels and the $\mathrm{AB}$ take to resolve a dispute on average?), as well as information in time-series mode, which allows the reader to observe whether trends emerge. ${ }^{19}$

19 The argument has been raised within the WTO that, although less disputes were submitted to the WTO in the second decade of its existence, the complexity of disputes has increased. It is of course difficult to measure complexity, and one of the relevant indicators to this effect could be the number of claims raised per dispute. In our 2011 paper, we provided evidence to the effect that the number of claims raised per dispute does not affect the overall duration of the process. Other factors as well could of course affect 'complexity'. In this vein we could think of novel issues that had never been raised before, or of issues that had been addressed in incoherent manner in case law. Anyway and for whatever reasons, the WTO has substantially increased the number of lawyers working in the various Divisions of the WTO dealing with dispute settlement. From less than ten in total at the moment of creation of the WTO, almost sixty lawyers are now being employed, and over one third of them has been hired in the last three years. Davey (2015), and Mavroidis (2015) discuss this issue in detail. 
Figure 5: Duration of Panel Proceedings

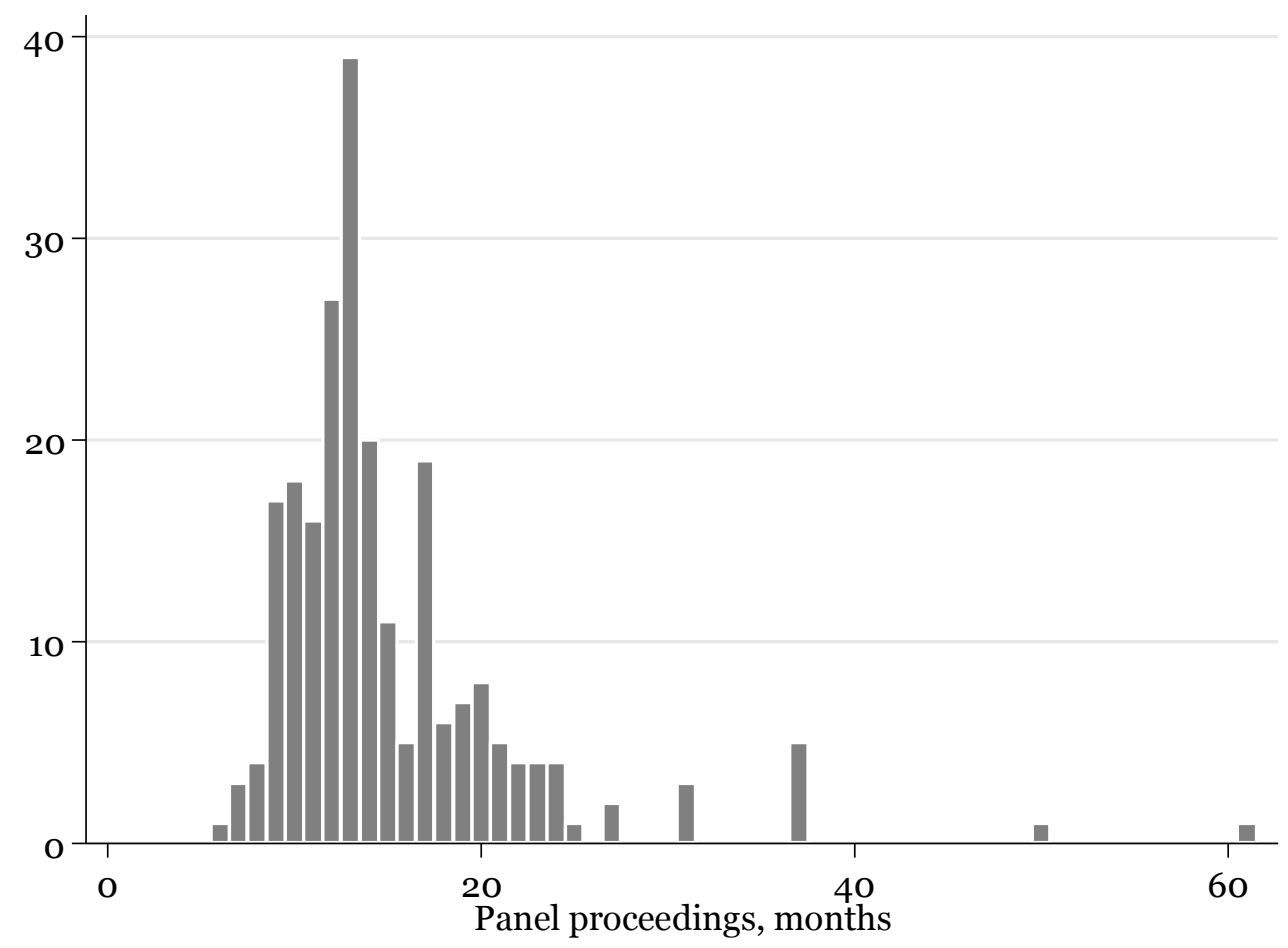

Table 5: Complainants and Defendants by Group at Panel Proceedings

\begin{tabular}{cc|ccccc} 
& \multicolumn{5}{c}{$\begin{array}{c}\text { Respondent } \\
\text { (Panel) }\end{array}$} \\
\cline { 3 - 6 } & & BRIC & DEV & G2 & IND & Total \\
\cline { 3 - 6 } $\begin{array}{c}\text { Complainant } \\
\text { (Panel) }\end{array}$ & DEIC & 7.0 & 12.0 & 13.7 & 11.0 & 13.4 \\
& G2 & 14.8 & 14.4 & 14.0 & 14.3 \\
& IND & 16.3 & 14.3 & 18.8 & 14.1 & 16.0 \\
& Total & 16.1 & 13.4 & 15.7 & 14.7 & 15.3 \\
& & & & & &
\end{tabular}




\section{Figure 6: Duration of AB Proceedings}

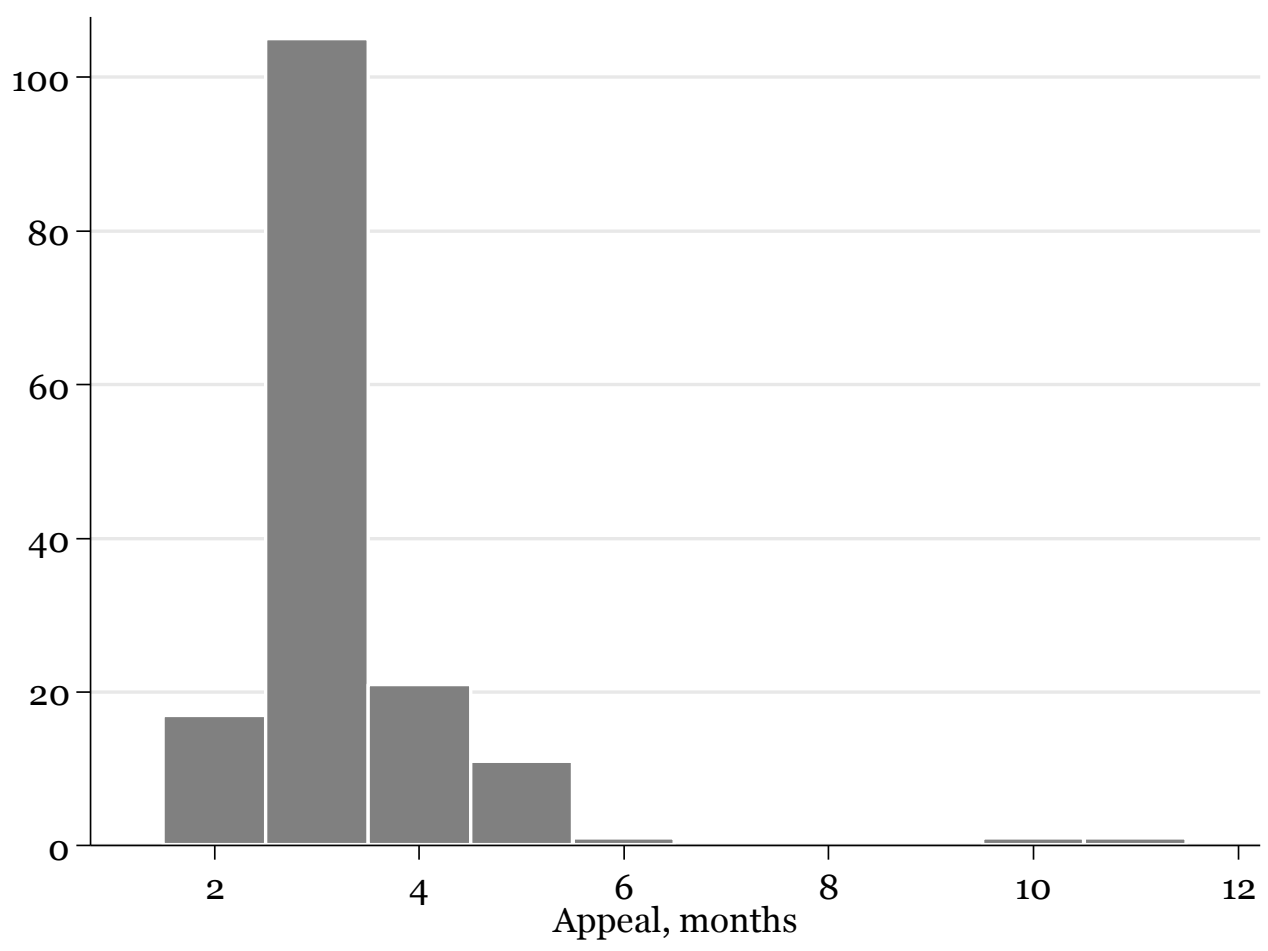

Table 6: Complainants and Defendants by Group at AB Proceedings

\begin{tabular}{|c|c|c|c|c|c|c|}
\hline & \multicolumn{4}{|c|}{$\begin{array}{l}\text { Respondent } \\
\text { (AB) }\end{array}$} & \multirow[b]{2}{*}{ Total } \\
\hline & & BRIC & DEV & G2 & IND & \\
\hline \multirow{5}{*}{$\begin{array}{l}\text { Complainant } \\
\text { (AB) }\end{array}$} & BRIC & & & 3.3 & 3.0 & 3.2 \\
\hline & $\mathrm{DEV}$ & 2.0 & 4.0 & 3.0 & & 3.1 \\
\hline & G2 & 3.4 & 2.9 & 4.1 & 2.9 & 3.4 \\
\hline & IND & 4.0 & 4.0 & 3.2 & 2.8 & 3.3 \\
\hline & Total & 3.5 & 3.4 & 3.3 & 2.9 & 3.3 \\
\hline
\end{tabular}


Figure 7: Duration of Panel Proceedings in Time-Series Mode

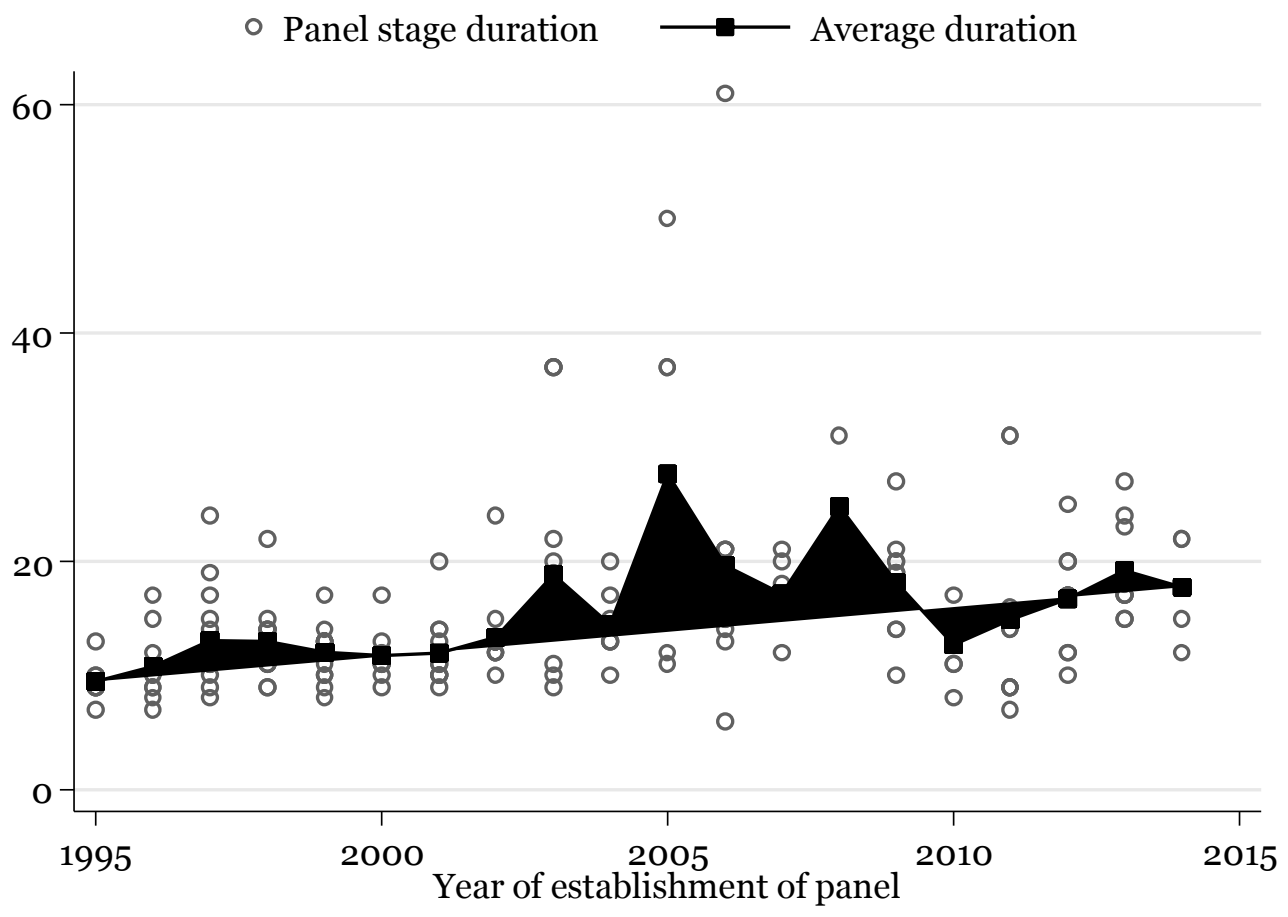

Figure 8: Duration of AB Proceedings in Time-Series Mode

$\circ \mathrm{AB}$ stage duration $\longrightarrow$ Average duration

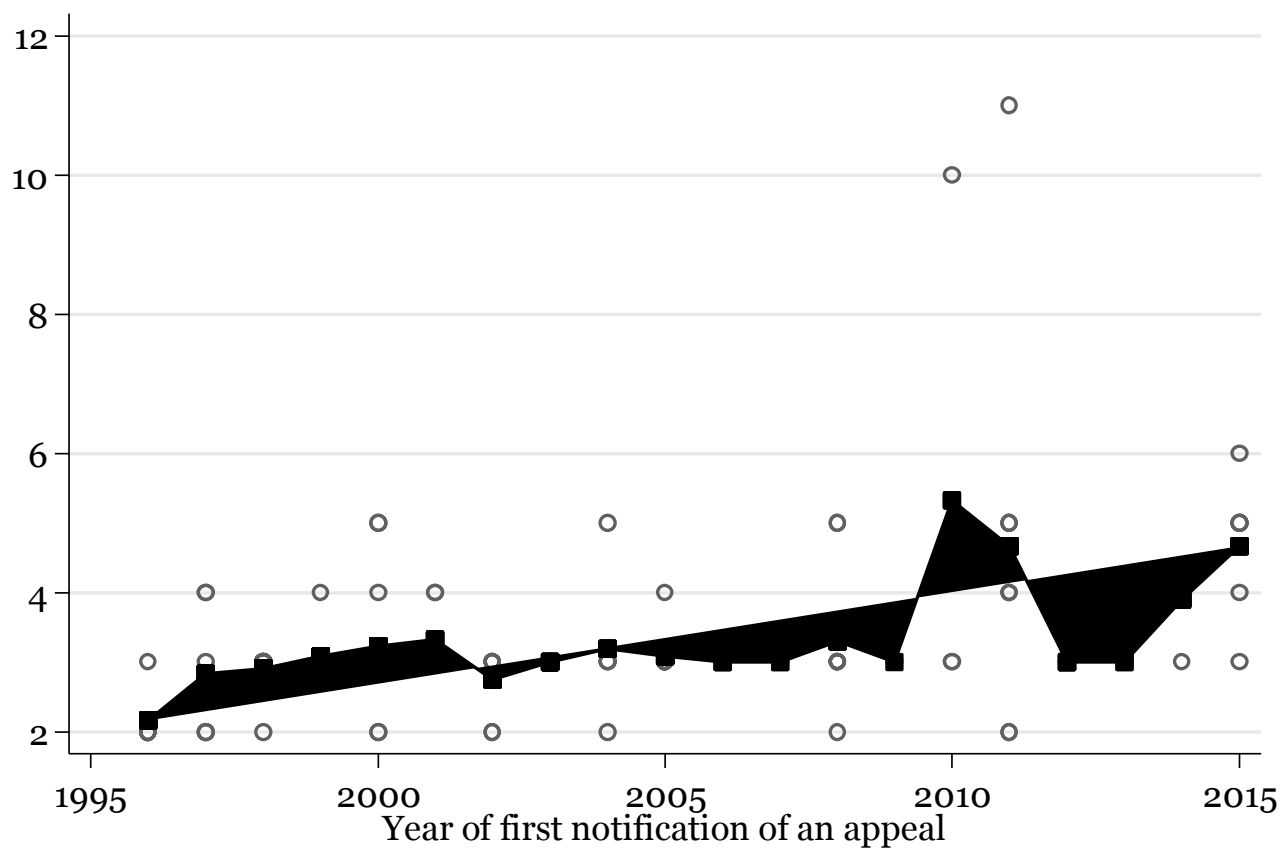




\subsection{Practice Defies Statutes}

In light of the above, one might legitimately ask the question whether it makes sense to readjust the statutory deadlines, which panels for one consistently overstep. Some discussion to this effect has already taken place in the context of the ongoing DSU Review. ${ }^{20}$ Arguments in favour and against have been heard, the latter focusing on the disciplining effect of 'tight' deadlines which, if absent, could lead panels to spend even more time per dispute.

\section{The Institutional Players}

We now turn our attention to the institutional players in WTO dispute adjudication. By 'institutional players', one usually understands the WTO members of course, the WTO judges (panelists and AB members), and the members of the WTO Secretariat that participate in proceedings. ${ }^{21}$ Nevertheless, we restrict our discussion to the former two categories. ${ }^{22}$ This is so, because information regarding the members of the Secretariat participating in proceedings as clerks is not available. Originally, the various documents issued in disputes mentioned the name of WTO officer acting as law clerk in disputes. ${ }^{23}$ Subsequently, nevertheless, the WTO Secretariat discontinued this practice.

\subsection{Parties to a Dispute}

WTO members have discretion to vary the intensity of their participation in a dispute. They can choose to act as complainants, or third party depending on considerations of their own. Their impact on the eventual decision will vary correspondingly. We explain.

\subsubsection{The Intensity of Participation}

A WTO member can autonomously decide whether it will act as complainant or third party. The decision is not inconsequential. Third parties have reduced rights before panels and the AB. First, their arguments do not have to be addressed by panels and/or the $\mathrm{AB}$, which can conveniently disregard them. In practice, their arguments will be reflected in the factual part of reports. Second, third parties cannot appeal panel reports (Article 17.4 of DSU). Furthermore, WTO members cannot participate as third parties before the $\mathrm{AB}$, unless if they have participated under the same capacity before a panel (Article 17.4 of DSU). The saving grace here is that WTO members that did not participate as third parties before a panel, can still participate as amici curiae before the $\mathrm{AB}$. The $\mathrm{AB}$ ruled as much in favour of Morocco in EC-Sardines.

Third parties do not have to intervene during proceedings. They can simply assist in the meeting (and receive the documents distributed in the first panel meeting and/or the only $\mathrm{AB}$ meeting with the

20 This process aims to update the current DSU in light of experience earned from practice so far. It is formally delinked from the also ongoing but moribund Doha round. The WTO Secretariat has been periodically issuing documents explaining the progress during negotiations (TN/DS series), and the last comprehensive paper issued explaining the progress so far is WTO Doc. TN/DS/28 of December 4, 2015.

21 Article 27.1 of DSU puts leaves us with no doubt as to the institutional function of the WTO Secretariat to assist panel during proceedings.

22 This does not mean that we side with the view that the participation of WTO Secretariat in dispute settlement proceedings is inconsequential. For one, under Article 8.6 of DSU, the Secretariat has crucial role in proposing panelists, as we detail later in this Section. Furthermore, there are good reasons to believe that the WTO Secretariat participates quite actively in the preparation of reports. Nordström (2005), and Johannesson and Mavroidis (2015) have expressed similar views on this score.

23 Indeed, we have included these references in our data set. 
parties, since, unlike panels, $\mathrm{AB}$ meets with the parties only once),${ }^{24}$ they can make an oral statement, or a written statement as well. The Definitions Section of the AB Working Procedures ${ }^{25}$ distinguishes between third parties and third participants. Third party, in accordance with the WP:

means any WTO Member who has notified the DSB of its substantial interest in the matter before the panel pursuant to paragraph 2 of Article 10 of the DSU.

Third participant, in the same document:

means any third party that has filed a written submission pursuant to Rule 24(1); or any third party that appears at the oral hearing, whether or not it makes an oral statement at that hearing.

The distinction is pertinent in light of the fact that some third parties might decide not to file before the AB. Third participants are hence, a sub-set of third parties: any third participant must be a third party; the opposite is not necessarily true, however.

Participation as third party can, of course, comport other benefits. Brazil, and China used this institutional possibility quite actively, and thus accustomed the personnel of their delegations to the WTO procedures.

WTO members, irrespective whether they act as complainants (defendants) or third parties, can autonomously decide on the composition of their delegation. Based on this decision, the AB opened the way in its report on EC-Bananas III to the possibility for WTO members to be represented by private attorneys before the WTO adjudicating bodies.

With this in mind, we now turn to our data.

\subsubsection{Who Complains against Who?}

We kick off our discussion with a presentation of the litigating pairs, at the consultations- and the panel stage, and we also include a table with the most frequent bilateral disputes. Unsurprisingly, we find that the bigger markets are the most frequent targets, and act as defendants more frequently than they act as complainants themselves.

\footnotetext{
${ }^{24}$ Panels retain discretion to grant enhanced third party rights to applicants that can demonstrate an interest to this effect, see for example EC-Hormones here the panel upheld the request by Canada and the US to act as enhanced third party in each other's complaint against the EU ( $\$ 8.15)$, and the AB upheld the manner in which the panel had exercised discretion on this issue ( $\$ 154)$.

25 WTO Doc. WT/AB/WP/6 of August 16, 2010.
} 
The WTO Dispute Settlement System 1995-2016: A Data Set and its Descriptive Statistics

Table 7: Who Complains Against Whom in Requests for Consultations?

\begin{tabular}{ll|cccccc} 
& & \multicolumn{5}{c}{ Respondent } \\
\cline { 3 - 6 } & & BRIC & DEV & G2 & IND & Total \\
\cline { 2 - 6 } Complainant & 1 & 8 & 48 & 8 & 65 \\
& DEV & 7 & 45 & 57 & 17 & 126 \\
& G2 & 53 & 33 & 63 & 55 & 204 \\
& IND & 17 & 18 & 72 & 26 & 133 \\
& LDC & 1 & 0 & 0 & 0 & 1 \\
& Total & 79 & 104 & 240 & 106 & 529
\end{tabular}

Table 8: Who Complains Against Whom in Requests for Establishment of a Panel?

\begin{tabular}{|c|c|c|c|c|c|c|}
\hline & \multicolumn{5}{|c|}{$\begin{array}{l}\text { Respondent } \\
\text { (Panel) }\end{array}$} \\
\hline & & BRIC & $\mathrm{DEV}$ & G2 & IND & Total \\
\hline \multirow{5}{*}{$\begin{array}{l}\text { Complainant } \\
\text { (Panel) }\end{array}$} & BRIC & 0 & 3 & 33 & 3 & 39 \\
\hline & DEV & 2 & 26 & 34 & 10 & 72 \\
\hline & G2 & 33 & 19 & 37 & 32 & 121 \\
\hline & IND & 8 & 11 & 57 & 14 & 90 \\
\hline & Total & 43 & 59 & 161 & 59 & 322 \\
\hline
\end{tabular}


Table 9: The Most Frequent Bilateral Disputes

\begin{tabular}{|c|c|c|c|c|c|}
\hline WTO Memb & sers & \# Disputes & WT & Members & \# Disputes \\
\hline $\mathrm{EU}$ & US & 63 & Dominican Republic & Honduras & 3 \\
\hline China & US & 26 & EU & Guatemala & 3 \\
\hline Canada & US & 20 & $\mathrm{EU}$ & Honduras & 3 \\
\hline India & $\mathrm{EU}$ & 17 & $\mathrm{EU}$ & Norway & 3 \\
\hline Korea & US & 17 & $\mathrm{EU}$ & Panama & 3 \\
\hline Canada & $\mathrm{EU}$ & 15 & Japan & Korea & 3 \\
\hline Mexico & US & 15 & Pakistan & US & 3 \\
\hline Argentina & EU & 14 & Argentina & Peru & 2 \\
\hline Brazil & US & 14 & Australia & Philippines & 2 \\
\hline India & US & 14 & Brazil & Japan & 2 \\
\hline Japan & US & 14 & Canada & Korea & 2 \\
\hline Brazil & $\mathrm{EU}$ & 12 & Chile & Colombia & 2 \\
\hline China & EU & 11 & Chile & Peru & 2 \\
\hline Argentina & US & 10 & China & Japan & 2 \\
\hline Argentina & Chile & 7 & Chinese Taipei & India & 2 \\
\hline $\mathrm{EU}$ & Japan & 7 & Costa Rica & Dominican Republic & 2 \\
\hline $\mathrm{EU}$ & Korea & 7 & Costa Rica & Trinidad and Tobago & 2 \\
\hline $\mathrm{EU}$ & Russia & 7 & Czech Republic & Hungary & 2 \\
\hline Indonesia & US & 7 & $\mathrm{EU}$ & Pakistan & 2 \\
\hline Australia & US & 6 & EU & Peru & 2 \\
\hline EU & Mexico & 6 & Ecuador & Mexico & 2 \\
\hline Chile & EU & 5 & India & Turkey & 2 \\
\hline EU & Thailand & 5 & Indonesia & Japan & 2 \\
\hline Philippines & US & 5 & Indonesia & New Zealand & 2 \\
\hline Thailand & US & 5 & Moldova & Ukraine & 2 \\
\hline Brazil & Canada & 4 & New Zealand & US & 2 \\
\hline China & Mexico & 4 & Russia & Ukraine & 2 \\
\hline $\mathrm{EU}$ & Indonesia & 4 & Turkey & US & 2 \\
\hline Guatemala & Mexico & 4 & US & Venezuela & 2 \\
\hline Argentina & Brazil & 3 & US & Viet Nam & 2 \\
\hline Australia & $\mathrm{EU}$ & 3 & & & \\
\hline Canada & China & 3 & & & \\
\hline Canada & Japan & 3 & & & \\
\hline Chile & US & 3 & & & \\
\hline Colombia & Panama & 3 & & & \\
\hline
\end{tabular}




\subsubsection{Frequency of Participation}

There is substantial literature regarding what are the factors influencing participation in the DSU. ${ }^{26}$ In fact, there is abundant literature, and it would be a quixotic test for us if we were to look for an exhaustive overview of the existing literature. In an effort to provide a flavour of the existing literature, we could mention some earlier efforts by Horn et al. (2005) to link participation to export trade shares, in the sense that the higher the volume of trade, the likelier that participation in dispute settlement proceedings will occur. ${ }^{27}$ Wickens (2009) explores whether bargaining power considerations can help explain participation. Nordström and Shaffer (2008) look into characteristics of those members with reduced bargaining power, such as the (lack of) capacity to determine trade barriers, the usually low monetary volumes associated with their trade. They conclude that participation of this type of countries (small developing countries) would be greatly enhanced if they could submit their disputes to small claims tribunals, that would provide fast relief. In similar vein, Conti (2010) looks into the manner in which presence or absence of legal expertise in national administrations affects participation in proceedings. More recently, Mavroidis and Sapir (2015) examine to what extent participation in free trade areas reduces the volume of disputes trading partners had experienced between them.

We start the presentation of our data with a Table explaining the propensity to join in consultations. Under the DSU, when an (original) complainant requests consultations, it must submit its request to both the designated defendant, as well as the WTO Secretariat. The latter will circulate it to the membership. Any member which wishes to act as co-complainant, can do so at this moment. The defendant nevertheless, must accede to this request (Article 4.11 of DSU). Even if the defendant refuses to accede though, there is still a gain for the eventual co-complainant(s), since they have now received information that they were not aware of before. In a way thus, multilateralization of Requests for Consultation subsidizes those WTO members that have hard time to detect (illegal) trade barriers, and process their (in-)consistency with the WTO. Information is a costly commodity, after all.

\footnotetext{
26 We are focusing on participation as complainant here. Defendants do not have discretion, since they are targets of actions.

27 Horn et al. (2005)
} 
Table 10: Propensity to Join in Consultations by Group

\begin{tabular}{|c|c|c|c|c|c|}
\hline Complainant & Respondent & $\begin{array}{l}\text { Request for } \\
\text { consultations }\end{array}$ & $\begin{array}{c}\text { Request to } \\
\text { join consultations }\end{array}$ & Total & $\begin{array}{c}\text { Propensity to } \\
\text { join }\end{array}$ \\
\hline \multirow{5}{*}{ BRIC } & BRIC & 1 & 0 & 1 & 0.0 \\
\hline & DEV & 8 & 6 & 14 & 42.9 \\
\hline & G2 & 48 & 93 & 141 & 66.0 \\
\hline & IND & 8 & 2 & 10 & 20.0 \\
\hline & Total & 65 & 101 & 166 & 60.8 \\
\hline \multirow{5}{*}{ DEV } & BRIC & 7 & 9 & 16 & 56.3 \\
\hline & DEV & 45 & 51 & 96 & 53.1 \\
\hline & G2 & 57 & 114 & 171 & 66.7 \\
\hline & IND & 17 & 66 & 83 & 79.5 \\
\hline & Total & 126 & 240 & 366 & 65.6 \\
\hline \multirow{5}{*}{ G2 } & BRIC & 53 & 123 & 176 & 69.9 \\
\hline & DEV & 33 & 71 & 104 & 68.3 \\
\hline & G2 & 63 & 143 & 206 & 69.4 \\
\hline & IND & 55 & 46 & 101 & 45.5 \\
\hline & Total & 204 & 383 & 587 & 65.2 \\
\hline \multirow{5}{*}{ IND } & BRIC & 17 & 70 & 87 & 80.5 \\
\hline & DEV & 18 & 32 & 50 & 64.0 \\
\hline & G2 & 72 & 174 & 246 & 70.7 \\
\hline & IND & 26 & 32 & 58 & 55.2 \\
\hline & Total & 133 & 308 & 441 & 69.8 \\
\hline LDC & BRIC & 1 & 1 & 2 & 50.0 \\
\hline
\end{tabular}


Figure 9: The Groups Acting as Complainants in Requests for Consultations in Time-Series Mode

\section{Complainant}

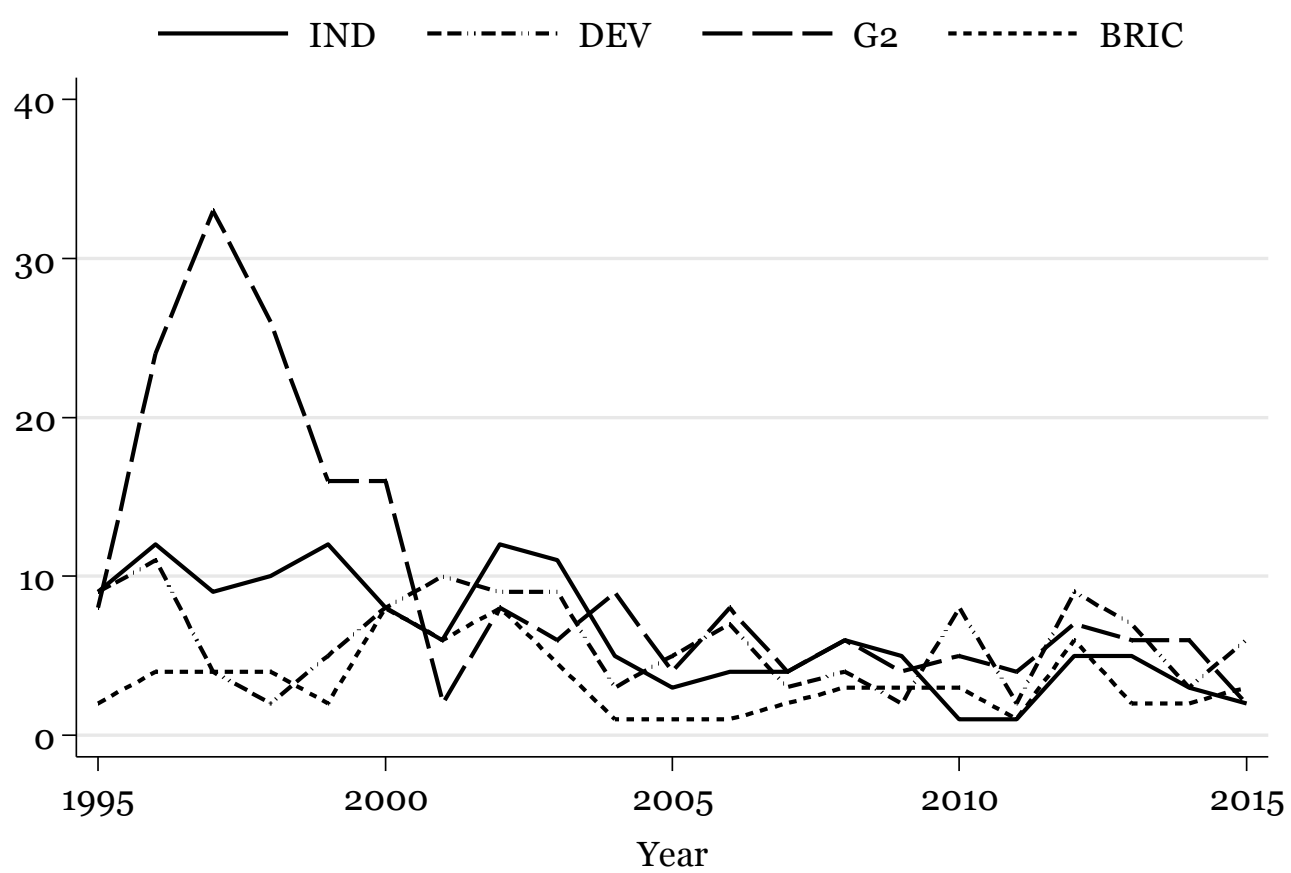

Figure 10: The Groups Acting as Defendants in Requests for Consultations in Time Series Mode

Respondent

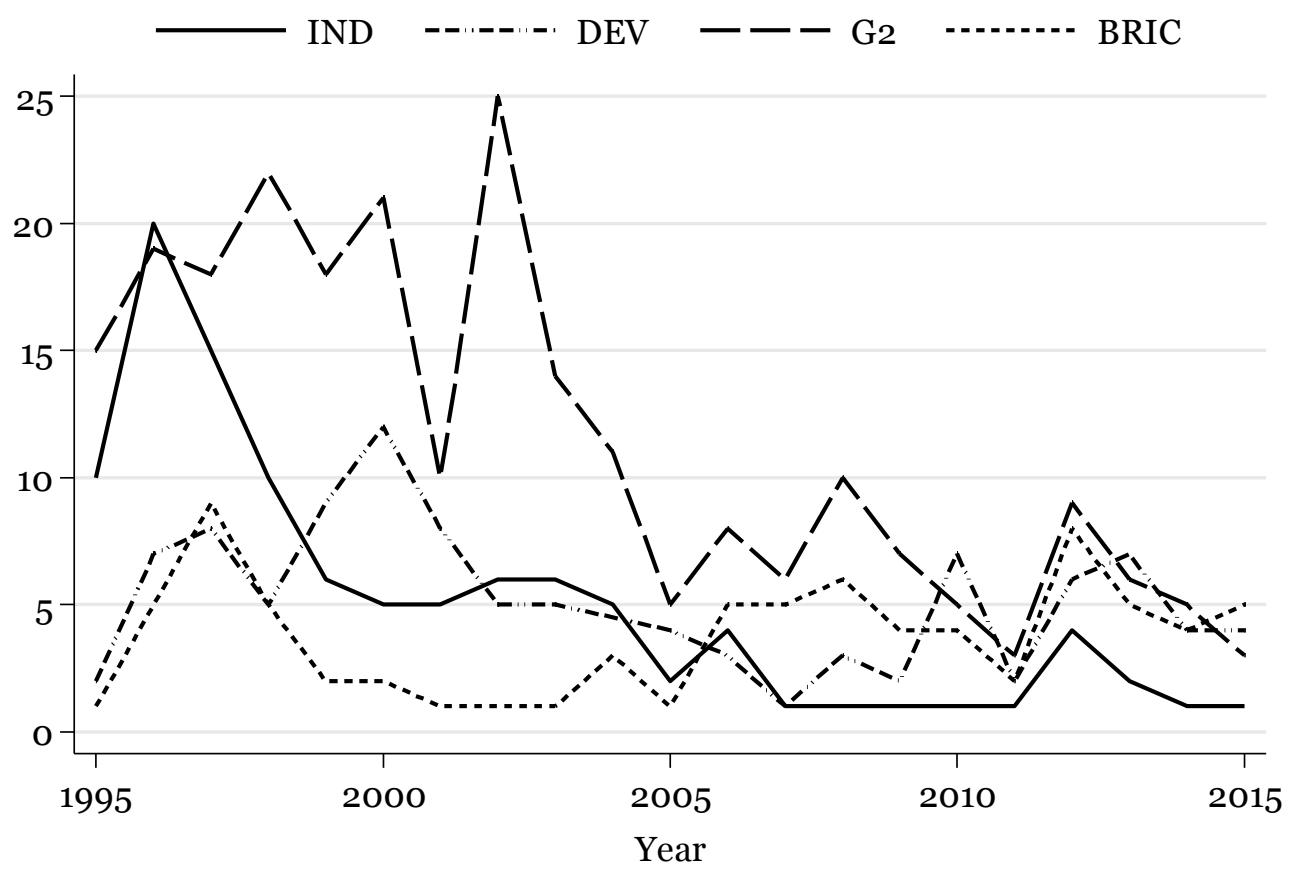


The data presented above seems consistent with the idea that export trade shares matter for participation purposes. Whereas the G2 dominated the early years of the WTO dispute settlement, acting as complainant in a very healthy percentage of cases, its share of disputes has dwindled over time. At the same time, the rise of China as a force to be reckoned with in international trade, has been accompanied by a surge in the number of disputes it has raised.

\subsubsection{Winners and Losers}

We now move to discuss whether, irrespective of their frequency of participation, WTO members win or lose symmetrically before the WTO adjudicating bodies. To do that, we need to establish our benchmark for 'victory' and 'defeat', our unit of account so to speak. This is far from being obvious, as we really need to transcend the ostensible in this respect.

Take for example, Mexico-Telecoms. In this case, US complains and wins its dispute to the effect that, the Mexican owner of telecoms network, Telmex, was contravening its obligations under the Telecoms Reference Paper. Mexico did not appeal the report. The US emerged victorious from the dispute, but did Mexico lose? The Mexican government was now in position to request from Telmex to change its access pricing policy, without being accused that it was taming on its own initiative an important player, that might be contributing to the government itself. Mexico could use GATT as an excuse to do something it wanted to do anyway itself, since the gains for consumer welfare resulting from the lowering of prices were quite substantial.

In similar vein, in EC-Bananas III, Ecuador, one of the complainants, won, and EU, the defendant lost, at least on paper. Did Ecuador win though? For Ecuador trade in bananas represents a substantial percentage of its GDP (gross domestic product), and EU one of its most lucrative markets. Well, it lost the EU market for more than twenty years, since the EU changed its policy only in $2011 .^{28}$ Ecuador never received any compensation for the loss of trade during these years, and, wisely, did not make matters worse for it by imposing countermeasures, as it could against the EU. Did the EU lose? Well, its member states concerned placated the domestic lobby they cared about (distributors of bananas) by refusing to compromise and implement an adverse AB ruling, 'buying' thus their political support for twenty years.

We could go on and cite many similar examples. And it is not political economy only that makes the pronouncement of a winner and loser a judgment call. Think of a case where a WTO member invokes various provisions, and prevails in some and not in others. How do we distinguish between 'important' and 'unimportant' claims in similar scenarios? The simple point we want to drive home is this: deciding on overall winners and losers is risky business. This is why we have used a different benchmark to decide on this score, the individual claims presented. According to Article 6.2 of the DSU, as interpreted in the AB report on Korea-Dairy Products, a Request for Establishment of a Panel must include all claims, that is, all factual situations a complainant complains about, and the legal provision they run counter. It is true that WTO panels, and the $\mathrm{AB}$, can decide on fewer than the total number of claims on judicial economy grounds, since, their mandate as per Article 7.1 of DSU is:

to make such findings as will assist the DSB in making the recommendations or in giving the rulings provided for in that/those agreement(s).

Judicial economy nevertheless, does not negatively affect our chosen approach, since it cuts across all cases, and there is no evidence that it is exercised asymmetrically across players.

With these explanations in mind we now turn to our data.

28 Guth (2012). 
Figure 11: Percentage of Successful Claims as Complainant or Defendant by Group

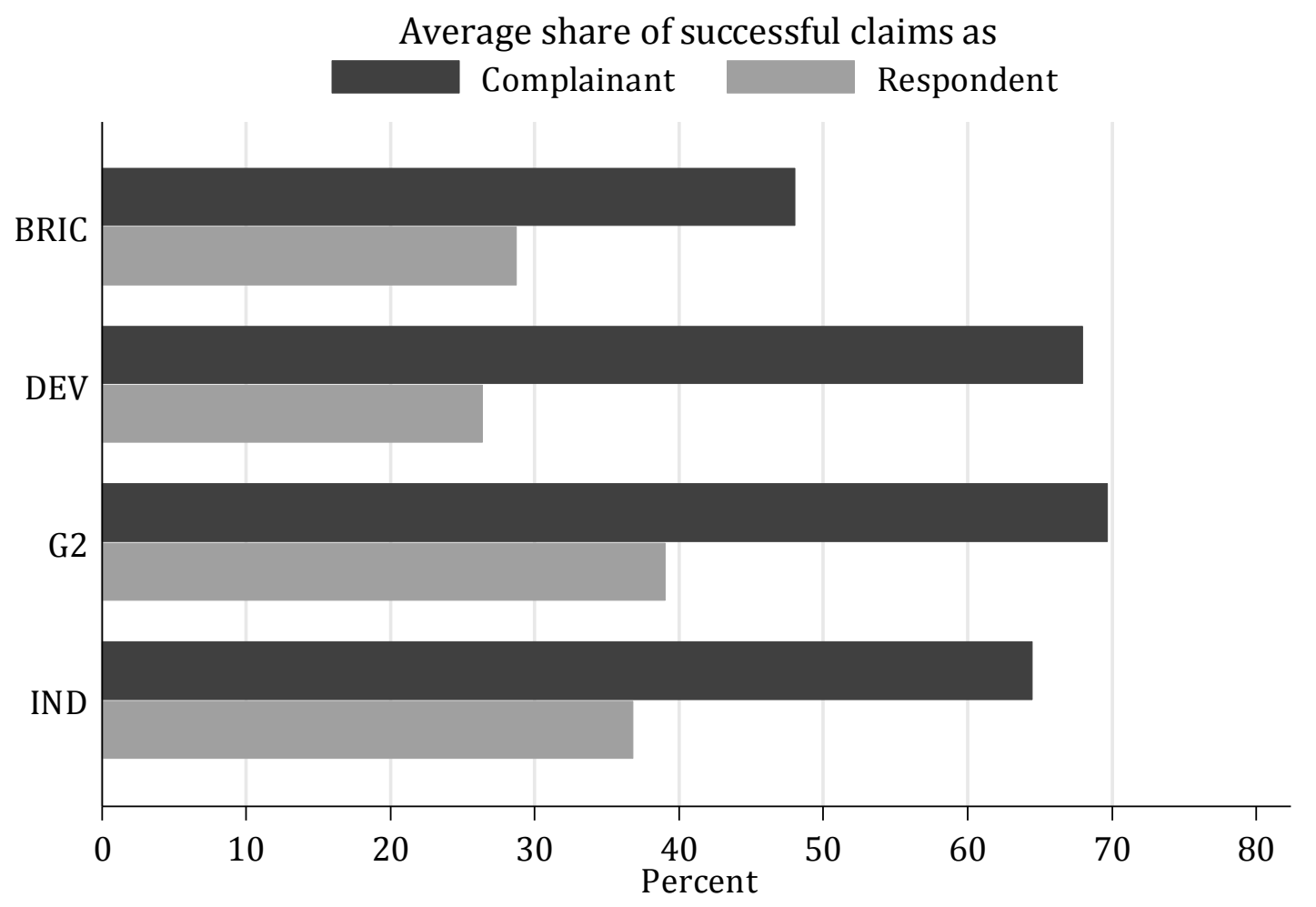

We disaggregate the information included in this Figure into the following two tables.

Table 11: Percentage of Successful Claims as Complainant by Group

\begin{tabular}{|c|c|c|c|c|c|c|}
\hline & \multicolumn{4}{|c|}{$\begin{array}{l}\text { Respondent } \\
\text { (Panel) }\end{array}$} & \multirow[b]{2}{*}{ Total } \\
\hline & & BRIC & DEV & G2 & IND & \\
\hline \multirow{4}{*}{$\begin{array}{c}\text { Complainant } \\
\text { (Panel) }\end{array}$} & BRIC & & 69.0 & 46.7 & 37.0 & 47.3 \\
\hline & DEV & & 82.3 & 63.2 & 38.8 & 65.9 \\
\hline & G2 & 69.4 & 92.4 & 65.0 & 73.5 & 69.6 \\
\hline & IND & 79.4 & 55.0 & 60.8 & 70.0 & 61.9 \\
\hline
\end{tabular}

Table 12: Percentage of Successful Claims as Respondent by Group

\begin{tabular}{ccccccc} 
& \multicolumn{5}{c}{$\begin{array}{c}\text { Complainant } \\
\text { (Panel) }\end{array}$} \\
\cline { 3 - 7 } & & \multicolumn{1}{c}{ BRIC } & DEV & G2 & \multicolumn{1}{c}{ IND } & Total \\
\cline { 3 - 6 } & BRIC & & & 30.3 & 20.6 & 28.9 \\
Respondent & DEV & 31.0 & 17.7 & 7.6 & 45.0 & 24.3 \\
(Panel) & G2 & 53.3 & 36.8 & 35.0 & 39.2 & 41.5 \\
& IND & 63.0 & 61.2 & 26.5 & 30.0 & 37.5
\end{tabular}


Remarkably, the percentage of winning complainants increases substantially so, when it is the DG, and not the parties, that appoints panelists. ${ }^{29}$

\section{Table 13: Percentage of Successful Claims as Complainant when DG or Parties Decide on Composition of Panelists (Aggregate Results)}

\begin{tabular}{lcc} 
& DG & Parties \\
\hline Complainant & 64.7 & 52.2 \\
Respondent & 35.3 & 47.8 \\
\hline
\end{tabular}

Our data thus, seems supports the view that there is a process of self-selection of disputes. WTO members pick winners, and do not litigate ad nauseam. Furthermore, the percentage of victories is almost symmetrically distributed across the various groups, lending thus support to the view that legal expertise can be easily outsourced.

\subsubsection{Third Parties}

As we have already explained, Articles 10, and 17.4 of DSU allow for third party participation of WTO members to disputes raised by other members. Note that none of the two provisions mentioned here assumes what the position of third parties is. As a result, there are examples of third parties' submissions siding with the complainant, as there are others siding with the defendant. In what follows, we provide information regarding the identity of third party participation before panels and the $\mathrm{AB}$.

\section{Table 14: Third Parties before Panels}

\begin{tabular}{lccc} 
Third party & $\begin{array}{c}\text { No of Members who have } \\
\text { been Third parties }\end{array}$ & $\begin{array}{c}\text { Number of Third party } \\
\text { appearances for group }\end{array}$ & $\begin{array}{c}\text { Group's share of all } \\
\text { Third party appearances }\end{array}$ \\
\hline BRIC & 4 & 258 & 15.5 \\
\hline DEV & 54 & 606 & 36.4 \\
\hline G2 & 2 & 209 & 12.5 \\
\hline IND & 15 & 578 & 34.7 \\
\hline LDC & 6 & 15 & 0.9 \\
\hline Total & 81 & 1666 & 100 \\
\hline
\end{tabular}

*Third party frequency is not based on bilateral disputes. Hence, a third party is only counted once for each distinct DS number.

29 We discuss the procedures for appointing panelists in 3.2 in this Section. 
Table 15: Third Parties before the AB

\begin{tabular}{cccc} 
Third party & $\begin{array}{c}\text { No. of Members } \\
\text { who have been } \\
\text { Third parties }\end{array}$ & $\begin{array}{c}\text { Number of Third } \\
\text { party appearances } \\
\text { for group }\end{array}$ & $\begin{array}{c}\text { Group's share of all } \\
\text { Third party } \\
\text { appearances }\end{array}$ \\
\hline BRIC & 4 & 124 & 16.6 \\
\hline DEV & 36 & 230 & 30.7 \\
\hline G2 & 2 & 95 & 12.7 \\
\hline IND & 12 & 293 & 39.2 \\
\hline LDC & 4 & 6 & 0.8 \\
\hline Total & 58 & 748 & 100 \\
\hline
\end{tabular}

*Third party frequency is not based on bilateral disputes. Hence, a Third party is only counted once for each distinct DS number. However, the joint submissions in DS267 and DS165 are counted for each individual WTO Member.

\subsection{Judges}

WTO judges are divided into panelists (serving panels, that is the 'first instance WTO courts'), and $\mathrm{AB}$ members (serving the $\mathrm{AB}$, the 'second instance WTO court'). The process for selecting each of the two categories differs, as we explain in what follows. The process of selection is, of course, not the only area of interest when it comes to understanding the role and function of WTO judges in the adjudication process. Ideally we would like to have information about the role of the WTO Secretariat in drafting reports, the remuneration of judges, the manner in which personal conflicts are managed at the WTO-level, the background of judges, ${ }^{30}$ etc. Alas, the standing increase in the amount of information notwithstanding, we have to rely on secondary sources in order to shed light on say remuneration, ${ }^{31}$ and/or the role of the Secretariat. ${ }^{32}$ This is why we have limited our work to the areas we can systematically research, such as, the origin of judges, the frequency of their appointment, and, when it comes to panelists only, whether they have been appointed by the parties or the DG.

Recall that panelists can appear as members of the original panel, the compliance panel, and as Arbitrator to decide on the level of compensation under Article 22.6 of DSU. If there is no supervening conflict or event that makes their appearance an impossibility, the members of the original panel will also compose the compliance panel, as well as the Arbitration body. AB members, besides serving on the $\mathrm{AB}$ are routinely appointed as arbitrators to decide the reasonable period of time within which compliance should occur. ${ }^{33}$

With this in mind, we first discuss the legal framework in place for appointing judges, before we move to present our data.

\footnotetext{
30 To be fair, there is some information about education and professional experience of panelists, and even more for $\mathrm{AB}$ members. It is nonetheless, highly asymmetric. As a result, including similar reference into the data set would give the wrong impression regarding the background of the totality of especially panelists.

31 Johannesson and Mavroidis (2015); Pauwelyn (2015).

32 Nordström (2005).

33 Mavroidis et al. (2017) provide an exhaustive data set on this score.
} 


\subsubsection{The Process for Selecting Panelists}

According to Article 8.1 of DSU:

Panels shall be composed of well-qualified governmental and/or non-governmental individuals, including persons who have served on or presented a case to a panel, served as a representative of a Member or of a contracting party to GATT 1947 or as a representative to the Council or Committee of any covered agreement or its predecessor agreement, or in the Secretariat, taught or published on international trade law or policy, or served as a senior trade policy official of a Member.

Expertise is not the only relevant criterion. Panelists must exhibit demonstrable independence (Article 8.2 of DSU), a quality that is better appreciated were one to take into account that many panelists, as per Article 8.1 of DSU and in practice, are members of delegations to the WTO. To this effect, they have to sign a document whereby they are required to indicate any existing or supervening conflict. ${ }^{34}$ The requirement for independence is further strengthened through Article 8.3 of DSU, which bars nationals of complainants and defendants, and even third parties to a dispute from acting as panellists, unless of course, parties to the dispute have agreed ${ }^{35}$ to their selection. ${ }^{36}$

The WTO Secretariat will keep a list of potential panellists, that is, a pool of individuals from which panelists to a specific dispute will be selected (Article 8.4 of DSU). The list is thus, of indicative nature, since inclusion does not automatically lead to selection. The list comprises both governmental as well as nongovernmental potential panelists. It is WTO members that propose individuals to be included in the list during the regular DSB meetings, and they can indicate whether the proposed individuals are experts in one or more areas of WTO law. To our knowledge, no proposal for inclusion in the list has been thwarted so far, probably because inclusion is inconsequential.

Following the request for establishment of a panel, the secretariat will meet the parties in order to compose the panel. To this effect, it will propose names that the parties can reject only for compelling reasons (Article 8.6 of DSU). There is no case law on this score, although proposals by the Secretariat are routinely rejected, otherwise there we would not be witnessing request to the DG to complete the panel, as we detail in what follows. Note that the Secretariat can propose even nonroster panelists, that is, individuals that have not been proposed for inclusion to the roster by WTO members. A panel will be composed of three or five panelists (Article 8.5 of DSU). In the WTO-era panels have always been composed of three individuals so far, and it is only in the early GATT years that panels had been composed of five persons.

If parties to the dispute do not manage to agree on one or more panelists within twenty days counting from the day of establishment of the panel, they can request from the DG to complete or appoint the full panel (Article 8.7 of DSU). The DG will do so within ten days, after consulting the Chairman of DSB, as well as the Chairman of the relevant Council or Committee. ${ }^{37}$

It becomes quite obvious from our discussion above that the Secretariat is quite influential in panel appointments. Officials of the WTO have the right to propose, and the DG has a right to decide on

34 WTO Doc. WT/DSB/RC/1 of December 11, 1996. This document includes the Rules of Conduct that not only panelists, and AB members, but also experts appearing before the WTO courts, as well as members of the WTO Secretariat must observe.

35 This has happened only exceptionally, for example in US-Zeroing (EC), where the parties to the dispute (EU, US) agreed to the selection of two of their nationals (Hans Beseler, EU; William J. Davey, US) to serve as panelists.

36 Nationality is of course, not necessarily a reason for bias. Nevertheless, there is some intellectual legitimacy in this provision, since the majority of panelists, as Johannesson and Mavroidis (2015) have shown, are in the service of governmental function.

37

In disputes involving alleges inconsistencies with the Antidumping Agreement for example, the DG will consult with the Chair of the Council for Trade in Goods, as well as the Chair for the Antidumping Committee. 
appointments. ${ }^{38}$ This is not the case when it comes to appointing $\mathrm{AB}$ members, as we detail in what immediately follows.

\subsubsection{The Process for Selecting AB Members}

The $\mathrm{AB}$ comprises seven members appointed for a mandate of four years renewable once (Article 17.1 DSU). Candidates must correspond to the requirements embedded in Article 17.3 of DSU, which largely reflect the corresponding discussion we have already entertained regarding the selection of panelists:

The $A B$ shall comprise persons of recognized authority, with demonstrated expertise in law, international trade and the subject matter of the covered agreements generally. They shall be unaffiliated with any government. The $\mathrm{AB}$ membership shall be broadly representative of membership in the WTO. All persons serving on the AB shall be available at all times and on short notice, and shall stay abreast of dispute settlement activities and other relevant activities of the WTO. They shall not participate in the consideration of any disputes that would create a direct or indirect conflict of interest.

Originally, that is, at the time when the first $\mathrm{AB}$ was composed, a Preparatory Committee was established (where delegates at the DSB could participate) in order to decide on the selection process for the members of the AB. Following a recommendation by this body, the DSB decided that an organ be established comprising the DG of the WTO, and the Chairmen of the General Council, the DSB, the CTG (Council for Trade in Goods), the CTS (Council for Trade in Services), and the TRIPs (tradeRelated Intellectual Property Rights) Council. This organ would be receiving propositions for nominations by WTO members, and, at the end, propose to the DSB its nominees. It is the DSB that would appoint the members of the $\mathrm{AB} .{ }^{39}$

Art. 17.1 DSU states that three rotating members of the AB (a division) will hear a case. The formula for selection of a division is not reflected in the DSU or in its Working Procedures, and is unknown to the wider public (Rule 6 of the Working Procedures). ${ }^{40}$ A presiding member for each division will be selected (Rule 7). Although a division hears and decides a particular case (Rule 3), a practice of collegiality has developed. In an effort to promote consistency and coherence in decisionmaking, Rule 4 reflects the so-called collegiality-requirement. According to its $\S 3$, the members of a division will exchange views with members of the $\mathrm{AB}$ who do not participate in their division, on the resolution of the dispute before them. It is the Division alone that will, of course, take the final decision.

\subsubsection{Data Regarding Panelists}

We start our discussion here with information regarding the question who appoints panelists, the parties to the dispute or the DG? In our view, this information is crucial for understanding (and avoid underestimating) the influence that the WTO Secretariat has on this score.

38 This procedure is unlike that applicable in investment arbitration, where parties to the dispute appoint one arbitrator each, and the two appointed arbitrators decide on the umpire, see Pauwelyn (2015) on this score. There is anecdotal evidence that parties to a WTO dispute have very exceptionally preempted the Secretariat's discretion to propose, by agreeing between them on panelists.

39 WTO Doc. WT/DSB/1.

40 Anecdotally, it seems that on its appointment, each member of the $\mathrm{AB}$ receives a number. A combination of three numbers, rotating according to a secret formula, will hear appeals as they are coming to the AB. For example, numbers 1 , 2 and 5 will hear appeal against DS 1, numbers 2, 6 and 9 will hear appeals against DS 2 and so on. What is unknown is the formula for rotating the divisions. 
Table 16: Frequency of Appointment by Parties and DG

\begin{tabular}{lcc} 
Appointment by & Freq. & Percent \\
\hline DG & 172 & 66.9 \\
Parties & 85 & 33.1 \\
\hline Total & 257 & 100
\end{tabular}

We now move to present data on the nationality of selected panelists, as well as on the frequency of appointment. Panelists do not enjoy a time-bound mandate like AB members do, and frequency of appointment is one criterion to measure their expertise to deal with issues coming under the purview of the WTO agreement.

Figure 12: National Origin of Panelists by Group

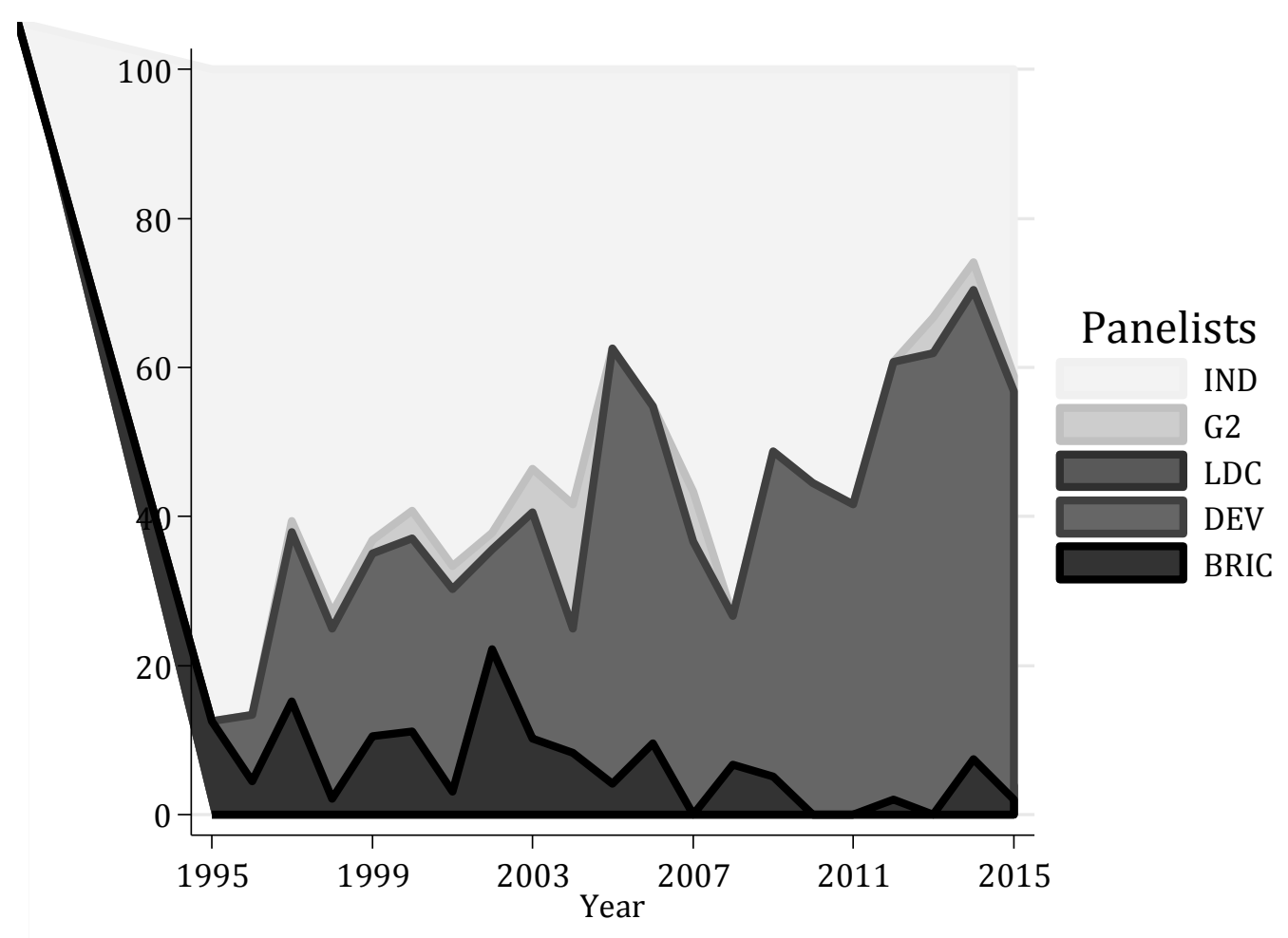


Table 17: National Origin of Panelists and Frequency of Appointment by Individual WTO Member

\begin{tabular}{|c|c|c|c|c|c|c|c|c|}
\hline IND & Freq. & Percent & DEV & Freq. & Percent & BRIC & Freq. & Percent \\
\hline New Zealand & 70 & 9.1 & South Africa & 37 & 4.8 & India & 31 & 4.0 \\
\hline Switzerland & 62 & 8.0 & Chile & 33 & 4.3 & Brazil & 25 & 3.2 \\
\hline Canada & 43 & 5.6 & Uruguay & 26 & 3.4 & Total & 56 & 7.3 \\
\hline Australia & 42 & 5.4 & Venezuela & 25 & 3.2 & & & \\
\hline Mexico & 25 & 3.2 & Colombia & 22 & 2.9 & G2 & Freq. & Percent \\
\hline Singapore & 25 & 3.2 & Argentina & 18 & 2.3 & US & 18 & 2.3 \\
\hline Hong Kong & 20 & 2.6 & Pakistan & 16 & 2.1 & & & \\
\hline Norway & 18 & 2.3 & Egypt & 13 & 1.7 & & & \\
\hline Japan & 14 & 1.8 & Philippines & 13 & 1.7 & & & \\
\hline Poland & 14 & 1.8 & Thailand & 10 & 1.3 & & & \\
\hline Israel & 13 & 1.7 & Costa Rica & 8 & 1.0 & & & \\
\hline Iceland & 12 & 1.6 & Jamaica & 6 & 0.8 & & & \\
\hline Czech Republic & 11 & 1.4 & Barbados & 5 & 0.6 & & & \\
\hline Germany & 10 & 1.3 & Ecuador & 5 & 0.6 & & & \\
\hline Korea & 9 & 1.2 & Morocco & 5 & 0.6 & & & \\
\hline Sweden & 9 & 1.2 & Indonesia & 3 & 0.4 & & & \\
\hline $\mathrm{UK}$ & 7 & 0.9 & Belize & 2 & 0.3 & & & \\
\hline Belgium & 5 & 0.6 & Guatemala & 2 & 0.3 & & & \\
\hline Finland & 5 & 0.6 & Malaysia & 2 & 0.3 & & & \\
\hline France & 3 & 0.4 & Mauritius & 2 & 0.3 & & & \\
\hline Ireland & 3 & 0.4 & Peru & 2 & 0.3 & & & \\
\hline Hong Kong & 2 & 0.3 & Taiwan & 2 & 0.3 & & & \\
\hline Hungary & 2 & 0.3 & Panama & 1 & 0.1 & & & \\
\hline Italy & 2 & 0.3 & Saudi Arabia & 1 & 0.1 & & & \\
\hline Portugal & 2 & 0.3 & Total & 259 & 33.6 & & & \\
\hline Slovenia & 2 & 0.3 & & & & & & \\
\hline Austria & 1 & 0.1 & & & & & & \\
\hline Bulgaria & 1 & 0.1 & & & & & & \\
\hline Netherlands & 1 & 0.1 & & & & & & \\
\hline Total & 433 & 56.2 & & & & & & \\
\hline
\end{tabular}

Table 18: Frequency of Appointment of Panelists by Group

\begin{tabular}{lcc} 
Panelists & Freq. & Percent \\
\hline IND & 433 & 56.2 \\
DEV & 259 & 33.6 \\
BRIC & 56 & 7.3 \\
G2 & 18 & 2.3 \\
LDC & 5 & 0.6 \\
\hline Total & 771 & 100
\end{tabular}


Table 19: Frequency of Appointment of Chairs by Group

\begin{tabular}{lcccccc}
\multicolumn{3}{c}{$1995-2015$} & & \multicolumn{2}{c}{$2011-2015$} \\
\cline { 1 - 2 } \cline { 6 - 7 } Panel Chairman & Freq. & Percent & & Freq. & Percent \\
\hline IND & 145 & 56.4 & & 23 & 39.7 \\
DEV & 83 & 32.3 & & 30 & 51.7 \\
BRIC & 17 & 6.6 & & 2 & 3.4 \\
G2 & 12 & 4.7 & & 3 & 5.2 \\
\hline Total & 257 & 100 & & 58 & 100
\end{tabular}

Table 20: Number of Repeat Panelists

\begin{tabular}{cccc}
$\begin{array}{c}\text { Number of panels that the } \\
\text { panelist has served on }\end{array}$ & Chair & Non-chair & Total no. of panelists \\
\hline 1 & 36 & 100 & 119 \\
\hline 2 & 24 & 41 & 53 \\
\hline 3 & 8 & 37 & 39 \\
\hline 4 & 4 & 15 & 17 \\
\hline 5 & 6 & 16 & 20 \\
\hline 6 & 8 & 7 & 10 \\
\hline 7 & 4 & 4 & 6 \\
\hline 8 & 2 & 2 & 3 \\
\hline 9 & & 1 & 1 \\
\hline 10 & & 6 & 6 \\
\hline 11 & 1 & & 1 \\
\hline 12 & & 1 & 1 \\
\hline 13 & & 1 & 1 \\
\hline 14 & & 1 & 279
\end{tabular}

\subsubsection{Data Regarding AB Members}

As already explained, $\mathrm{AB}$ members are appointed to serve by using a secret formula to this effect. The frequency thus, of their appointment depends on this formula, and, as a result, there are no dramatic discrepancies in the number of appearances across members of the AB. It could, of course, be the case that a particular member has a conflict and excuses itself from adjudicating a particular dispute. Similar occurrences nevertheless, are quite infrequent, and to some extent anticipated through the choices to appoint members. 
Table 21: Nationality of AB Members ${ }^{41}$

$\begin{array}{ll}\text { US } & 4 \\ \text { EU } & 3 \\ \text { Japan } & 3 \\ \text { China } & 2 \\ \text { Egypt } & 2 \\ \text { India } & 2 \\ \text { Korea } & 2 \\ \text { Philippines } & 2 \\ \text { Australia } & 1 \\ \text { Brazil } & 1 \\ \text { Mexico } & 1 \\ \text { New Zealand } & 1 \\ \text { Uruguay } & 1 \\ \text { South Africa } & 1\end{array}$

Table 22: Nationality of AB Members by Group

$\begin{array}{ll}\text { G2 } & 7 \\ \text { IND } & 8 \\ \text { BRIC } & 5 \\ \text { DEV } & 6\end{array}$

Table 23: Frequency of Appointment of AB Members

\begin{tabular}{lc} 
AB Member & Appeals \\
\hline James Bacchus & 34 \\
Georges-Michel Abi-Saab & 28 \\
Claus-Dieter Ehlermann & 27 \\
Julio Lacarte-Muró & 27 \\
A.V. Ganesan & 25 \\
Florentino P. Feliciano & 25 \\
Giorgio Sacerdoti & 24 \\
Yasuhei Taniguchi & 20 \\
\hline
\end{tabular}

41 We include in the data the two recent appointments that were decided on November 23, 2016, of Ms Zhao Hong (China), and Hyun Chong Kim (Korea). 


\title{
4. The Subject-Matter
}

The subject-matter of disputes is defined by the complainant. It is for the complainant to decide whether to litigate, and under what terms. In what follows, we include information regarding agreements and provisions invoked at the consultations-stage. ${ }^{42}$ The reason is that complainants cannot add new claims after they have issued their Request for Consultations. This is the case because of case law construction, and not because of statutory discipline. The AB has stated in its report on USShrimp (Thailand) at $\$ 293$ that:

\begin{abstract}
[a]s long as the complaining party does not expand the scope of the dispute, [it would] hesitate to impose too rigid a standard for the 'precise and exact identity' between the scope of the consultations and the request for the establishment of a panel, as this would substitute the request for consultations for the panel request". The Appellate Body has also held that a "precise and exact identity" of measures between the two requests is not necessary, "provided that the 'essence' of the challenged measures had not changed." In our view, whether a complaining party has "expand[ed] the scope of the dispute" or changed the "essence" of the dispute through the inclusion of a measure in its panel request that was not part of its consultations request must be determined on a case-by-case basis. (emphasis in the original)
\end{abstract}

As a result, when the complainant submits a Request for Establishment of panel, it will at most include the claims it had included in its Request for Consultations. The terms of reference for panels are explained in Article 7.1 of DSU:

Panels shall have the following terms of reference unless the parties to the dispute agree otherwise within 20 days from the establishment of the panel:

To examine, in the light of the relevant provisions in (name of the covered agreement(s) cited by the parties to the dispute), the matter referred to the DSB by (name of party) in document ... and to make such findings as will assist the DSB in making the recommendations or in giving the rulings provided for in that/those agreement(s).

This does not mean that panels (and/or the $\mathrm{AB}$ ) must agree with the legal qualification of facts as presented by the complainant. We need to distinguish between factual matter and legal issues though. In application of the Roman maxim (accepted in WTO case law through US-Wool Shirts and Blouses) actori incumbit probatio, it is the complainant that has the burden to prove the facts. It is courts on the other hand, as per the other foundational Roman maxi, jura novit curia, that are in charge of deciding on the correct legal basis and the subjugation of facts under it. This means that a discrepancy between what has been submitted, and what the final decision might include, since, for example, it could be that the complainant invoked the wrong legal basis. It could also be that, based on judicial economy grounds, panels (and/or the $\mathrm{AB}$ ) decide not to discuss some of the issues invoked.

In similar vein, the Notice of Appeal before the $\mathrm{AB}$ can at best include the issues decided by the panel the report of which is being appealed (Article 16.4 of DSU).

With this in mind, we turn now to the data.

\subsection{Invoking Agreements}

We kick off the presentation of our data in this respect with a presentation of aggregate results regarding the invocation of the three foundational agreements of the WTO, namely the GATT, the GATS, and the TRIPs, before we move to discuss some of the most frequently invoked agreements of Annex 1A (e.g., agreements on trade in goods, and thus, annexed to the GATT). The reason why we do not include information of agreements annexed to say trade in services is that, as can be easily observed, agreements on trade in goods almost monopolize the subject-matter of disputes before the WTO. There are many reasons why this has been the case that we do not need to get into for the

\footnotetext{
42 Our data set contains of course, information about provisions and agreements invoked before panels and the AB as well.
} 
purposes of this paper. Furthermore, we discuss only some of the Annex 1A agreements, namely the agreements regarding contingent protection (Antidumping, AD; Subsidies and Countervailing Measures, SCM; and Safeguards, SG), the Agreement on Technical Barriers to Trade (TBT), and the Agreement on Sanitary and Phytosanitary Measures (SPS). These five are the most frequently invoked agreements and the difference between invocations of these five and any other agreement belonging to Annex $1 \mathrm{~A}$ is very substantial.

Table 24: Frequency of Invocations of WTO Agreements in Requests for Consultations (Aggregate Results)

\begin{tabular}{lcc} 
Cited Agreement & Frequency & Percent \\
\hline GATT & 424 & 35 \\
\hline Antidumping (AD) & 121 & 10 \\
\hline Subsidies and Countervailing Measures (SCM) & 117 & 10 \\
\hline Agriculture (AG) & 85 & 7 \\
\hline WTO & 62 & 5 \\
\hline Technical Barriers to Trade (TBT) & 51 & 4 \\
\hline Import-Licensing Procedures (ILA) & 50 & 4 \\
\hline Safeguards (SG) & 47 & 4 \\
\hline Sanitary and Phyto-Sanitary Measures (SPS) & 44 & 4 \\
\hline Trade-Related Investment Measures (TRIMs) & 44 & 3 \\
\hline Trade-Related Intellectual Property Rights (TRIPs) & 34 & 2 \\
\hline Trade in Services (GATS) & 28 & 2 \\
\hline Protocol of Accession of the People's Republic of China & 22 & 1 \\
\hline Dispute Settlement Understanding (DSU) & 18 & 1 \\
\hline Customs Valuation (CV) & 17 & 1 \\
\hline Textiles and Clothing (ATP) & 16 & 1 \\
\hline Rules of Origin (ROO) & 7 & 0 \\
\hline Preshipment Inspection (PI) & 5 & 0 \\
\hline Enabling Clause & 4 & 0 \\
\hline Government Procurement (GPA) & 4 & 0 \\
\hline Paris Convention & 2 & 0 \\
\hline 1979 Understanding Regarding Notification, Consultation, & 1 & 0 \\
Dispute Settlement and Surveillance & 1 & 0 \\
\hline GATT 1947 & & 0 \\
\hline Ministerial Decision Regarding Cases Where Customs & 1,206 & \\
Administrations Have Reasons to Doubt the Truth or & & 0 \\
Accuracy of Declared Value & & 0 \\
\hline WTO Decision on Notification Procedures & & \\
\hline Total & & 0 \\
\hline *The number of times various WTO Agreements have been invoked in Request for Consultations. No \\
account is taken to how many articles are invoked under each agreement. This table is to show the \\
prevalence of agreements in Request for Consultation. & & \\
\hline
\end{tabular}


Table 25: Frequency of Invocations of GATT in Requests for Consultations by Group

\begin{tabular}{|c|c|c|c|c|c|c|}
\hline \multirow[t]{2}{*}{ Agreement } & \multirow[t]{2}{*}{ Complainant } & \multicolumn{4}{|c|}{ Respondent } & \multirow[b]{2}{*}{ Total } \\
\hline & & BRIC & $\mathrm{DEV}$ & G2 & IND & \\
\hline \multirow{6}{*}{ GATT } & BRIC & 1 & 5 & 40 & 4 & 50 \\
\hline & $\mathrm{DEV}$ & 7 & 41 & 49 & 15 & 112 \\
\hline & G2 & 46 & 25 & 40 & 36 & 147 \\
\hline & IND & 15 & 15 & 64 & 20 & 114 \\
\hline & LDC & 1 & 0 & 0 & 0 & 1 \\
\hline & Total & 70 & 86 & 193 & 75 & 424 \\
\hline
\end{tabular}

Table 26: Frequency of Invocations of GATS in Requests for Consultations by Group

\begin{tabular}{llcccc|c} 
Agreement & Complainant & \multicolumn{4}{c}{ Respondent } \\
\cline { 1 - 5 } & & BRIC & DEV & G2 & IND & Total \\
\cline { 3 - 6 } AG & BRIC & 0 & 1 & 5 & 0 & 6 \\
& DEV & 2 & 3 & 6 & 4 & 15 \\
& G2 & 7 & 7 & 8 & 13 & 35 \\
& IND & 5 & 4 & 10 & 10 & 29 \\
& Total & 14 & 15 & 29 & 27 & $\mathbf{8 5}$
\end{tabular}

Table 27: Frequency of Invocations of TRIPs in Requests for Consultations by Group

\begin{tabular}{|c|c|c|c|c|c|c|}
\hline \multirow[t]{2}{*}{ Agreement } & \multirow[t]{2}{*}{ Complainant } & \multicolumn{4}{|c|}{ Respondent } & \\
\hline & & BRIC & $\mathrm{DEV}$ & $\mathrm{G} 2$ & IND & Tota \\
\hline \multirow{5}{*}{ GATS } & BRIC & 0 & 0 & 1 & 0 & 1 \\
\hline & $\mathrm{DEV}$ & 0 & 2 & 7 & 1 & 10 \\
\hline & G2 & 5 & 0 & 4 & 4 & 13 \\
\hline & IND & 1 & 0 & 2 & 1 & 4 \\
\hline & Total & 6 & 2 & 14 & 6 & 28 \\
\hline
\end{tabular}


Table 28: Frequency of Invocations of Select Annex 1A Agreements (trade in Goods) in Requests for Consultations by Group

\section{AG, TRIMs, TBT, SPS, AD, SCM, SG}

\begin{tabular}{|c|c|c|c|c|c|c|}
\hline \multirow[t]{2}{*}{ Agreement } & \multirow[t]{2}{*}{ Complainant } & \multicolumn{4}{|c|}{ Respondent } & \\
\hline & & BRIC & $\mathrm{DEV}$ & G2 & IND & Total \\
\hline \multirow{5}{*}{ TRIMs } & BRIC & 0 & 0 & 3 & 0 & 3 \\
\hline & $\mathrm{DEV}$ & 0 & 0 & 6 & 0 & 6 \\
\hline & G2 & 11 & 8 & 1 & 4 & 24 \\
\hline & IND & 5 & 3 & 1 & 2 & 11 \\
\hline & Total & 16 & 11 & 11 & 6 & 44 \\
\hline \multirow{5}{*}{ TRIPs } & BRIC & 0 & 0 & 3 & 0 & 3 \\
\hline & $\mathrm{DEV}$ & 0 & 0 & 0 & 5 & 5 \\
\hline & G2 & 5 & 4 & 10 & 5 & 24 \\
\hline & IND & 0 & 0 & 2 & 0 & 2 \\
\hline & Total & 5 & 4 & 15 & 10 & 34 \\
\hline Agreement & \multirow[t]{2}{*}{ Complainant } & \multicolumn{4}{|c|}{ Respondent } & \\
\hline \multirow{6}{*}{ SPS } & & BRIC & $\mathrm{DEV}$ & G2 & IND & Total \\
\hline & BRIC & 0 & 1 & 2 & 0 & 3 \\
\hline & $\mathrm{DEV}$ & 0 & 1 & 4 & 4 & 9 \\
\hline & G2 & 4 & 0 & 4 & 8 & 16 \\
\hline & IND & 0 & 0 & 8 & 8 & 16 \\
\hline & Total & 4 & 2 & 18 & 20 & 44 \\
\hline \multirow{5}{*}{ TBT } & BRIC & 0 & 2 & 2 & 0 & 4 \\
\hline & $\mathrm{DEV}$ & 1 & 0 & 9 & 6 & 16 \\
\hline & G2 & 1 & 2 & 7 & 4 & 14 \\
\hline & IND & 1 & 1 & 14 & 1 & 17 \\
\hline & Total & 3 & 5 & 32 & 11 & 51 \\
\hline
\end{tabular}




\begin{tabular}{|c|c|c|c|c|c|c|}
\hline Agreement & Complainant & & Respon & dent & & \\
\hline & & BRIC & $\mathrm{DEV}$ & G2 & IND & Total \\
\hline & BRIC & 1 & 4 & 20 & 2 & 27 \\
\hline & $\mathrm{DEV}$ & 3 & 9 & 15 & 3 & 30 \\
\hline $\mathrm{AD}$ & G2 & 8 & 2 & 9 & 5 & 24 \\
\hline & IND & 2 & 9 & 27 & 1 & 39 \\
\hline & $\mathrm{LDC}$ & 1 & 0 & 0 & 0 & 1 \\
\hline & Total & 15 & 24 & 71 & 11 & 121 \\
\hline & BRIC & 0 & 1 & 18 & 3 & 22 \\
\hline $\mathrm{S} C \mathrm{M}$ & $\mathrm{DEV}$ & 1 & 1 & 8 & 0 & 10 \\
\hline SCIVI & G2 & 16 & 5 & 18 & 14 & 53 \\
\hline & IND & 7 & 1 & 21 & 3 & 32 \\
\hline & Total & 24 & 8 & 65 & 20 & 117 \\
\hline & BRIC & 0 & 0 & 2 & 1 & 3 \\
\hline$S G$ & $\mathrm{DEV}$ & 0 & 17 & 3 & 0 & 20 \\
\hline Su & G2 & 0 & 4 & 5 & 1 & 10 \\
\hline & IND & 0 & 3 & 9 & 2 & 14 \\
\hline & Total & 0 & 24 & 19 & 4 & 47 \\
\hline
\end{tabular}

It is quite remarkable that twenty years on the WTO dispute settlement experience, disputes concerning practice in the realm of contingent protection instruments continue to represent a very high percentage of the overall litigation under the auspices of the WTO.

\subsection{Invoking Provisions}

In parallel with the discussion above, we first look into invocations of provisions of the three foundational agreements (GATT, GATS, TRIPs), before we move to discuss invocations of provisions of the five most frequently used Annex $1 \mathrm{~A}$ agreements. 
Table 29: Frequency of Invocations of GATT Provisions (Aggregate Results)

\begin{tabular}{lcc}
\multicolumn{3}{c}{ GATT } \\
\hline Articles & Freq.* & Percent \\
\hline I $(M F N)$ & 139 & 10.88 \\
\hline II & 118 & 9.23 \\
\hline III $(N T)$ & 224 & 17.53 \\
\hline IX & 4 & 0.31 \\
\hline V & 23 & 1.8 \\
\hline VI & 165 & 12.91 \\
\hline VII & 25 & 1.96 \\
\hline VIII & 25 & 1.96 \\
\hline X & 149 & 11.66 \\
\hline XI & 128 & 10.02 \\
\hline XIII & 59 & 4.62 \\
\hline XIX & 53 & 4.15 \\
\hline XV & 2 & 0.16 \\
\hline XVI & 11 & 0.86 \\
\hline XVII & 9 & 0.7 \\
\hline XVIII & 8 & 0.63 \\
\hline XX & 9 & 0.7 \\
\hline XXI & 2 & 0.16 \\
\hline XXIII & 104 & 8.14 \\
\hline XXIV & 8 & 0.63 \\
\hline XXVIII & 10 & 0.78 \\
\hline Procedures for Negotiations under Article XXVIII & 1 & 0.08 \\
\hline Understanding on the Interpretation of Article II & 1 & 0.08 \\
\hline Understanding on the Interpretation of Article XXVIII & 1 & 0.08 \\
\hline & 1278 & 100
\end{tabular}


Table 30: Frequency of Invocations of GATS Provisions (Aggregate Results)

GATS

\begin{tabular}{lcc}
\hline Articles & Freq.* $^{*}$ & Percent \\
\hline I & 1 & 1 \\
\hline II $(M F N)$ & 18 & 17.5 \\
\hline III & 3 & 2.9 \\
\hline IV & 5 & 4.9 \\
\hline VI & 9 & 8.7 \\
\hline VIII & 2 & 1.9 \\
\hline XI & 2 & 1.9 \\
\hline XVI (Market Access) & 23 & 22.3 \\
\hline XVII (NT) & 26 & 25.2 \\
\hline XVIII & 4 & 3.9 \\
\hline XXIII & 3 & 2.9 \\
\hline TRP & 4 & 3.9 \\
\hline Annex on Movement of Natural & 1 & 1 \\
Persons Supplying Services & 2 & 1.9 \\
\hline Annex on Telecommunications & 103 & 100
\end{tabular}


Table 31: Frequency of Invocations of TRIPs Provisions (Aggregate Results)

\begin{tabular}{|c|c|c|c|c|c|}
\hline \multicolumn{3}{|c|}{ TRIPs } & & & \\
\hline Articles & Freq.* & Percent & Articles & Freq.* & Percent \\
\hline 1 & 4 & 2.1 & 28 & 6 & 3.2 \\
\hline 2 & 10 & 5.3 & 31 & 3 & 1.6 \\
\hline $3(N T)$ & 11 & 5.8 & 33 & 3 & 1.6 \\
\hline $4(M F N)$ & 4 & 2.1 & 34 & 1 & 0.5 \\
\hline 7 & 1 & 0.5 & 39 & 3 & 1.6 \\
\hline 8 & 1 & 0.5 & 41 & 9 & 4.8 \\
\hline 9 & 5 & 2.7 & 42 & 5 & 2.7 \\
\hline 10 & 2 & 1.1 & 46 & 1 & 0.5 \\
\hline 11 & 2 & 1.1 & 49 & 2 & 1.1 \\
\hline 12 & 2 & 1.1 & 50 & 7 & 3.7 \\
\hline 13 & 2 & 1.1 & 51 & 2 & 1.1 \\
\hline 14 & 5 & 2.7 & 52 & 1 & 0.5 \\
\hline 15 & 5 & 2.7 & 53 & 2 & 1.1 \\
\hline 16 & 8 & 4.2 & 54 & 1 & 0.5 \\
\hline 17 & 1 & 0.5 & 55 & 1 & 0.5 \\
\hline 18 & 1 & 0.5 & 58 & 1 & 0.5 \\
\hline 19 & 1 & 0.5 & 59 & 2 & 1.1 \\
\hline 20 & 8 & 4.2 & 61 & 4 & 2.1 \\
\hline 21 & 1 & 0.5 & 62 & 2 & 1.1 \\
\hline 22 & 5 & 2.7 & 63 & 6 & 3.2 \\
\hline 24 & 5 & 2.7 & 65 & 19 & 10.1 \\
\hline 27 & 11 & 5.8 & 70 & 13 & 6.9 \\
\hline
\end{tabular}


Table 32: Frequency of Invocations of Annex 1A( Trade in Goods) Agreements (Aggregate Results)

\begin{tabular}{ccc}
\multicolumn{3}{c}{ TBT } \\
\hline Articles & Freq. $^{*}$ & Percent \\
\hline 1 & 1 & 0.8 \\
\hline 2 & 79 & 61.7 \\
\hline 3 & 3 & 2.3 \\
\hline 5 & 27 & 21.1 \\
\hline 6 & 4 & 3.1 \\
\hline 7 & 2 & 1.6 \\
8 & 1 & 0.8 \\
\hline 9 & 1 & 0.8 \\
\hline 12 & 7 & 5.5 \\
\hline 15 & 1 & 0.8 \\
\hline 16 & 1 & 0.8 \\
\hline 22 & 1 & 0.8 \\
\hline Total & 128 & 100
\end{tabular}

\begin{tabular}{ccc}
\multicolumn{3}{c}{ SPS } \\
\hline Articles & Freq.* $^{*}$ & Percent \\
\hline 1 & 2 & 0.3 \\
\hline 2 & 62 & 21.2 \\
\hline 3 & 27 & 9.3 \\
\hline 4 & 8 & 2.7 \\
\hline 5 & 93 & 31.9 \\
\hline 6 & 18 & 6.2 \\
\hline 7 & 17 & 5.8 \\
\hline 8 & 19 & 6.5 \\
\hline 10 & 5 & 1.7 \\
\hline 13 & 1 & 0.3 \\
\hline Annex B & 20 & 6.9 \\
\hline Annex C & 20 & 6.9 \\
\hline Total & 292 & 100
\end{tabular}

*The number of times various articles have been invoked in the Request for Consultations by the original complainants. An Article is counted only once even if referred to several times. Hence, if for instance SCM or AD, Arts. 3.1 and 3.2 have been both invoked, the Table counts this as one invocation of Art. 3. Equivalently, if for instance GATT Art. III.1 and III.2 have been both invoked; the Table counts this as one invocation of Art. III 
Table 33: Frequency of Invocations of Provisions in the AD, SCM, and SG Agreements

$\mathrm{AD}$

\begin{tabular}{ccc}
\hline Article & Freq. & Percent \\
\hline 1 & 78 & 5.0 \\
\hline 2 & 241 & 15.4 \\
\hline 3 & 247 & 15.8 \\
\hline 4 & 31 & 2.0 \\
\hline 5 & 153 & 9.8 \\
\hline 6 & 281 & 18.0 \\
\hline 7 & 39 & 2.5 \\
\hline 8 & 15 & 1.0 \\
\hline 9 & 109 & 7.0 \\
\hline 10 & 9 & 0.6 \\
\hline 11 & 66 & 4.2 \\
\hline 12 & 90 & 5.8 \\
\hline 15 & 7 & 0.4 \\
\hline 15 & 13 & 0.8 \\
\hline 16 & 1 & 0.1 \\
\hline 17 & 5 & 0.3 \\
\hline 18 & 97 & 6.2 \\
\hline 19 & 1 & 0.1 \\
\hline Annex I & 6 & 0.4 \\
\hline Annex II & 75 & 4.8 \\
\hline Total & 1564 & 100
\end{tabular}

SCM

\begin{tabular}{ccc}
\hline Articles & Freq. & Percent \\
\hline 1 & 66 & 8.57 \\
\hline 2 & 37 & 4.81 \\
3 & 93 & 12.08 \\
\hline 4 & 24 & 3.12 \\
\hline 5 & 41 & 5.32 \\
\hline 6 & 53 & 6.88 \\
\hline 7 & 13 & 1.69 \\
\hline 10 & 49 & 6.36 \\
\hline 11 & 60 & 7.79 \\
\hline 12 & 40 & 5.19 \\
\hline 13 & 8 & 1.04 \\
\hline 14 & 23 & 2.99 \\
\hline 15 & 54 & 7.01 \\
\hline 16 & 4 & 0.52 \\
\hline 17 & 16 & 2.08 \\
\hline & & \\
\hline
\end{tabular}




\begin{tabular}{ccc}
\hline 18 & 11 & 1.43 \\
\hline 19 & 39 & 5.06 \\
20 & 2 & 0.26 \\
\hline 21 & 26 & 3.38 \\
\hline 22 & 23 & 2.99 \\
\hline 25 & 9 & 1.17 \\
\hline 27 & 11 & 1.43 \\
\hline 28 & 2 & 0.26 \\
\hline 30 & 1 & 0.13 \\
\hline 32 & 56 & 7.27 \\
\hline Annex I & 6 & 0.78 \\
\hline Annex II & 2 & 0.26 \\
\hline Annex III & 1 & 0.13 \\
\hline Total & 770 & 100
\end{tabular}

\begin{tabular}{ccc}
\multicolumn{3}{c}{ SG } \\
\hline Articles & Freq. & Percent \\
\hline 2 & 56 & 15.26 \\
3 & 49 & 13.35 \\
4 & 99 & 26.98 \\
\hline 5 & 41 & 11.17 \\
\hline 6 & 13 & 3.54 \\
\hline 7 & 24 & 6.54 \\
\hline 8 & 14 & 3.81 \\
\hline 9 & 12 & 3.27 \\
\hline 11 & 14 & 3.81 \\
\hline 12 & 45 & 12.26 \\
\hline Total & 367 & 100
\end{tabular}

\section{Concluding Remarks}

Our data covers many issues we could not, for reasons of space constraints, highlight here. We tried to focus on some of its salient features. The WTO dispute settlement system has entered the twenty-third year of its existence. It has provoked diametrically opposite reactions across commentators. It has been hailed as the 'crown jewel' of the system, but also criticized for failing to 'complete' the contract through methodologically sound reasoning and understanding of the various provisions. It has been heralded as promoting compliance, but also been criticized for doing the opposite by insisting on forward looking compliance, that is, be continuously recommending prospective remedies. ${ }^{43}$

Irrespective of the criticism though, one thing is clear. The WTO dispute settlement system remains the only comprehensive compulsory third party adjudication regime, a means to promote peaceful resolution in the old Hullian approach. And there is no signs of abandoning it either. Independent research by Li and Qiu (2015), looking into over one hundred free trade areas, and Mavroidis and Sapir (2015), looking into the behavior of the G2, confirms that, even though preferential partners tend

$43 \mathrm{Wu}$ (2015) offers thoughts in this respect. 
to reduce (sometimes) drastically their litigation before the WTO, this is not because they have decided to divert their litigation to a different forum. The WTO continues to be the privileged forum for solving trade disputes. This is probably its greatest strength. 


\section{References}

Bhagwati, Jagdish. 1990. Aggressive Unilateralism: an Overview, pp. 1-48 in Jagdish Bhagwati and Hugh Patrick (eds.), Aggressive Unilateralism, America's 301 Trade Policy and the World Trading System, Harvester Wheatsheaf: New York City, NY.

Bown, Chad P., and Rachel Brewster. 2016. US-COOL Retaliation: the WTO's Article 22.6 Arbitration, Peterson Institute Working Paper 16-13, Peterson Institute of International Economics: Washington DC.

Busch, Marc L., and Eric Reinhardt. 2001. Bargaining in the Shadow of Law: Early Settlement in GATT/WTO Disputes, Fordham International Law Journal, 24: 158-172.

Conti, Joseph. 2010. Learning to Dispute: Repeat Participation, Expertise and Contribution at the WTO, Law and Social Inquiry, 35: 623-662.

Davey, William J. 2015. The First Years of WTO dispute Settlement: Dealing with Controversy and Building Confidence, Chapter 25 in Gabrielle Marceau (ed.), A History of Law and Lawyers in the GATT/WTO, Cambridge University Press \& the WTO: Geneva, Switzerland.

Davey, William J. 2014. The WTO and Rules-Based Dispute Settlement: Historical Evolution, Operational Success and Future Challenges, Journal of International Economic Law, 17: 679-700.

Guth, Eckart. 2012. The End of the Bananas Saga, Journal of World Trade, 46: 1-32.

Guzman, Andrew, and Beth Simmons. 2003. To Settle or Empanel? An Empirical Analysis of Litigation and Settlement at the WTO, Journal of Legal Studies, 31: 205-231.

Hippler Bello Judith, and Alan F. Holmer. 1990. The Heart of the 1988 Trade Act: a Legislative History of the Amendments to Section 301, pp. 49-90 in Jagdish Bhagwati and Hugh Patrick (eds.), Aggressive Unilateralism, America's 301 Trade Policy and the World Trading System, Harvester Wheatsheaf: New York City, NY.

Horn, Henrik, Louise Johannesson, and Petros C. Mavroidis. 2011. The WTO Dispute Settlement System: 1995-2010, Some Descriptive Statistics, Journal of World Trade, 45: 1107-1138.

Horn, Henrik, Petros C. Mavroidis, and Håkan Nordström. 2005. Is the Use of Dispute Settlement System Biased?, pp. 454-486 in Petros C. Mavroidis \& Alan O. Sykes (eds.), The WTO and International Trade Law / Dispute Settlement, Elgar Publishing: Cheltenham, United Kingdom.

Hudec, Robert E. 1993. Enforcing International trade Law: the Evolution of the Modern GATT Legal System, Butterworth: Oxford, United Kingdom.

Hudec, Robert E. 1990. Thinking about the New Section 301: Beyond Good and Evil, pp. 113-159 in Jagdish Bhagwati and Hugh Patrick (eds.), Aggressive Unilateralism, America's 301 Trade Policy and the World Trading System, Harvester Wheatsheaf: New York City, NY.

Johannesson, Louise, and Petros C. Mavroidis. 2015. Black Cat, White Cat: the Identity of the WTO Judges, Journal of World Trade, 49: 685-698.

Li, Tan, and Larry D. Qiu. 2015. Beyond Trade Creation: Free Trade Agreements and Disputes, ERIA Discussion Papers Series, ERIA-DP-2015-28, ERIA: Jakarta, Indonesia.

Mavroidis, Petros C. 2016. Mind over Matter, pp. 333-378 in Kyle Bagwell and Robert W. Staiger (eds.), Handbook on Commercial Policy, Handbooks in Economics, Elsevier: Amsterdam and New York City.

Mavroidis, Petros C. 2016a. The Regulation of International Trade (vols. 1 \& 2), MIT Press: Massachusetts. 
Mavroidis, Petros C. 2015. Taking Care of Business: the Legal Affairs Division from the GATT to the WTO, Chapter 16 Gabrielle Marceau (ed.), A History of Law and Lawyers in the GATT/WTO, Cambridge University Press \& the WTO: Geneva, Switzerland.

Mavroidis, Petros C., Niall Meagher, Tom Prusa, Tatiana Yanguas. 2017. Ask for the Moon, Settle for the Stars, World Trade Review forthcoming.

Mavroidis, Petros C., and André Sapir. 2015. Dial PTAs for Peace: The Influence of Preferential Trade Agreements on Litigation between Trading Partners, Journal of World Trade, 49: 351-374.

Milner, Helen. 1990. The Political Economy of US Trade Policy: a Study of the Super 301 Provision, pp. 163-180 in Jagdish Bhagwati and Hugh Patrick (eds.), Aggressive Unilateralism, America's 301 Trade Policy and the World Trading System, Harvester Wheatsheaf: New York City, NY.

Nordström, Håkan. 2005. The WTO Secretariat in a Changing World, Journal of World Trade, 39: 819-853.

Nordström, Håkan, and Gregory Shaffer. 2008. Access to Justice in the WTO: a Case for a Small Claims Procedure, World Trade Review, 7: 587-640.

Palmeter, David N., and Petros C. Mavroidis. 2006. Dispute Settlement in the WTO, Practice and Procedure, Cambridge University Press: Cambridge, United Kingdom.

Pauwelyn, Joost. 2015. The Rule of Law Without the Rule of Lawyers? Why Investment Arbitrators Are from Mars, Trade Adjudicators Are from Venus, American Journal of International Law , 109: 761-805.

Schwartz, Warren F., and Alan O. Sykes. 2002. The Economic Structure of Renegotiation and Dispute Resolution in the World Trade Organization, Journal of Legal Studies, XXXI: 179-204.

Wickens, Sebastian. 2009. The Usage of the WTO Dispute Settlement System: Do Power Considerations Matter? pp. 213-241 in James Hartigan (ed.), Trade Disputes and the Dispute Settlement Understanding of the WTO, Emerald Publishing: Bingley, United Kingdom.

Wu, Mark. 2015. Rethinking the Temporary Breach Puzzle in International Trade Law: A Window on the Future of Trade Conflicts, Yale Journal of International Law, 40: 97-121. 


\section{Author contacts:}

\section{Louise Johannesson}

Research Institute of Industrial Economics (IFN)

ATTN: Louise Johannesson

Box 55665

10215 Stockholm

Sweden

Email: Louise.johannesson@ifn.se

\section{Petros C. Mavroidis}

Columbia Law School

435 W. 116th St

New York NY 10027

Email:pmavro@law.columbia.edu 